INTEGRATING STRATEGIC ENVIRONMENTAL ASSESSMENT INTO POWER DEVELOPMENT PLANNING IN VIET NAM

DECEMBER 2018 



\section{INTEGRATING STRATEGIC ENVIRONMENTAL ASSESSMENT INTO POWER DEVELOPMENT PLANNING IN VIET NAM}

DECEMBER 2018 
(c) 2018 Asian Development Bank

6 ADB Avenue, Mandaluyong City, 1550 Metro Manila, Philippines

Tel +632632 4444; Fax+6326362444

www.adb.org

Some rights reserved. Published in 2018.

ISBN 978-92-9261-478-2 (print), 978-92-9261-479-9 (electronic)

Publication Stock No. TCS199905

DOI: http://dx.doi.org/10.22617/TCS199905

The views expressed in this publication are those of the authors and do not necessarily reflect the views and policies of the Asian Development Bank (ADB) or its Board of Governors or the governments they represent.

ADB does not guarantee the accuracy of the data included in this publication and accepts no responsibility for any consequence of their use. The mention of specific companies or products of manufacturers does not imply that they are endorsed or recommended by ADB in preference to others of a similar nature that are not mentioned.

By making any designation of or reference to a particular territory or geographic area, or by using the term "country" in this document, $\mathrm{ADB}$ does not intend to make any judgments as to the legal or other status of any territory or area.

This work is available under the Creative Commons Attribution 3.0 IGO license (CC BY 3.0 IGO)

https://creativecommons.org/licenses/by/3.0/igo/. By using the content of this publication, you agree to be bound by the terms of this license. For attribution, translations, adaptations, and permissions, please read the provisions and terms of use at https://www.adb.org/terms-use\#openaccess.

This CC license does not apply to non-ADB copyright materials in this publication. If the material is attributed to another source, please contact the copyright owner or publisher of that source for permission to reproduce it. ADB cannot be held liable for any claims that arise as a result of your use of the material.

Please contact pubsmarketing@adb.org if you have questions or comments with respect to content, or if you wish to obtain copyright permission for your intended use that does not fall within these terms, or for permission to use the ADB logo.

Corrigenda to ADB publications may be found at http://www.adb.org/publications/corrigenda.

Notes:

In this publication, "\$” refers to United States dollars.

ADB recognizes "Vietnam” as Viet Nam.

All photos by ADB.

On the cover: Sunny Bangchak solar farm in Chaiyabhum Province (left) and A Vuong Reservoir (right). 


\section{Contents}

Tables and Figure

iv

Acknowledgments

Abbreviations

vi

Weights and Measures

vi

Executive Summary

vii

1 Introduction

1.1 Purpose and Rationale for the Report

1.2 Strategic Environmental Assessment

1.3 Summary of Traditional Power Development Plan Systems

2 Context

2.1 Understanding the Need to Change Power Sector Planning 10

2.2 Origins and Policies for Strategic Environmental Assessment 11

2.3 Wider Policy Context 12

$\begin{array}{ll}2.4 \text { Conclusions } & 18\end{array}$

3 Evolution of Strategic Environmental Assessments in Power Development 19

3.1 Strategic Environmental Assessment of the Hydropower Master Plan 19 in Power Development Plan VI

3.2 Strategic Environmental Assessment of Power Development Plan VII 23

$4 \quad$ Strategic Environmental Assessment of the Revised Power 31 Development Plan VII

4.1 Structure of the Revised Power Development Plan VII 31

4.2 Calculation of Externalities in the Revised Power Development Plan VII 34 Scenarios

4.3 Analysis of Impacts $\quad 35$

$\begin{array}{ll}4.4 \text { Conclusions } & 39\end{array}$

5 Remaining Challenges for Developing Strategic Environmental Assessments 41 of Power Development Plans

5.1 Introduction 41

5.2 Improving Power System Modeling Programs 42

5.3 Improving Input Database for Power System Modeling 42

5.4 Improving Relationship between Power Sector Planning Processes 44 in the National and Provincial Levels 


\section{Tables and Figure}

\section{Tables}

1 Comparison of Environmental Impact Assessment and Strategic

Environmental Assessment

2 Total Environmental Costs for Each Pollutant in the Original Power 24

Development Plan VII, 2011

3 Reduction of Pollutant Emissions Compared to the Base Case through Energy Efficiency Measures Relative to Base Case in the Original Power Development Plan VII, 2011

4 Reduction of Atmospheric Pollution from Expanded Renewable Energy Relative to Base Case in the Original Power Development Plan VII, 2011

5 Revised Power Development Plan VII Scenarios: First Iteration, 2016

6 Enhanced Renewable Energy Scenarios for Revised Power Development Plan VII, Second Additional Iteration, 2016

7 Predicted Flue Gas Emissions from Thermal Power Generation in the Different Scenarios of Revised Power Development Plan VII

8 Total Carbon Dioxide Emissions in 2015-2030: Power Development Plan VII versus Revised Power Development Plan VII Scenarios

\section{Figure}

Thermal Power Station Clusters in the North and South Regions-

Original Power Development Plan, 2011 


\title{
Acknowledgments
}

\begin{abstract}
- his report was prepared by the consultant team from the Asian Development Bank (ADB) under regional technical assistance 9003: Integrated Resource Planning with Strategic Environmental Assessment in the Greater Mekong Subregion, which is cofinanced with the Agence Francaise de Developpement (AFD).

John Soussan led the drafting of the report, with significant contributions from Don Webster and others in the team, under the supervision of Hyunjung Lee, senior energy economist, Energy Division, Southeast Asia Department (SERD). Colleagues from the Institute of Energy of the Ministry of Industry and Trade in Ha Noi, especially Nguyen Thi Thu Huyen and Nguyen Ngoc Hung, also contributed significantly.

The report was peer-reviewed by Sumit Pokhrel, environmental specialist, Environmental Operation Center, SERD, and Bruce Dunn, director, Sustainable Development and Climate Change Department. Guidance and support were provided by Ramesh Subramaniam, director general, SERD; Andrew Jeffries, director, Energy Division, SERD; and Eric Sidgwick, country director, Viet Nam Resident Mission. Lois Sevestre and Stéphane Tromilin provided valuable support from AFD.
\end{abstract}




\section{Abbreviations}

$\begin{array}{ll}\mathrm{CO}_{2} & \text { carbon dioxide } \\ \text { EIA } & \text { Environmental Impact Assessment } \\ \text { EVN } & \text { Vietnam Electricity } \\ \text { GDE } & \text { General Directorate of Energy } \\ \text { GDP } & \text { gross domestic product } \\ \text { GHG } & \text { greenhouse gas } \\ \text { GIS } & \text { geographic information system } \\ \text { GMS } & \text { Greater Mekong Subregion } \\ \text { INDC } & \text { Intended Nationally Determined Contribution } \\ \text { LEP } & \text { Law on Environmental Protection } \\ \text { MOIT } & \text { Ministry of Industry and Trade (Viet Nam) } \\ \text { NO } & \text { nitrogen oxides } \\ \text { NTP } & \text { National Target Program to Respond to Climate Change } \\ \text { PDP } & \text { Power Development Plan } \\ \text { PFES } & \text { Payment for Forest Environmental Services } \\ \text { PPC } & \text { Provincial People's Committee } \\ \text { RPDP VII } & \text { Revised Power System Development Plan 7 } \\ \text { pH } & \text { potential of hydrogen (a scale of acidity) } \\ \text { SEA } & \text { Strategic Environmental Assessment } \\ \text { SEDP } & \text { Socio-Economic Development Plan } \\ \text { SO } & \text { sulfur dioxide } \\ \text { TA } & \text { technical assistance } \\ \text { OECD } & \text { Organisation for Economic Co-operation and Development } \\ \text { UNFCCC } & \text { United Nations Framework Convention on Climate Change } \\ \text { WASP } & \text { Wien Automatic System Planning } \\ & \end{array}$

\section{Weights and Measures}

$\begin{array}{ll}\text { GWh } & \text { gigawatt-hour } \\ \text { ha } & \text { hectare } \\ \mathrm{kV} & \text { kilovolt } \\ \mathrm{kW} & \text { kilowatt } \\ \mathrm{kWh} & \text { kilowatt-hour } \\ \mathrm{MW} & \text { megawatt } \\ \mathrm{TWh} & \text { terawatt-hour } \\ \mathrm{TOE} & \text { ton of oil equivalent } \\ \mathrm{tCO}_{2} & \text { ton of carbon dioxide }\end{array}$




\section{Executive Summary}

n 2014, Asian Development Bank (ADB) published three knowledge products on the application of strategic environmental assessment (SEA) in the power sector in the Greater Mekong Subregion (GMS) under technical assistance (TA) 7764 on Ensuring Sustainability of GMS Regional Power Development: (i) Integrating SEA into Power Planning; (ii) Identifying Sustainability Indicators of SEA for Power Planning; and (iii) How SEA can Influence Power Development Plans-Comparing Alternative Scenarios for Power Planning in the GMS.

Under the subsequent TA 9003 on Integrated Resource Planning with Strategic Environmental Assessment in the GMS, this document lays out the experience of Viet Nam in the integration of a Strategic Environmental Assessment (SEA) in the preparation of the country's Power Development Plan (PDP). It traces the process of incorporating an SEA into the PDP. The latest version of Viet Nam's PDP - the revised PDP VII (RPDP VII) -is a model of good practice in integrating an SEA in the preparation of a strategic plan that is important not just for Viet Nam but for the power sector of other countries, particularly in the Greater Mekong Subregion. This SEA has provided an understanding of the implications of the different development options in the PDP, leading to significant changes in the final contents of the plan and ensuring that it is better aligned to national development policies of Viet Nam. This demonstrates how incorporating an SEA into the planning process will produce plans that are based on a more thorough understanding of their implications for the economy, society, and environment of the country.

An SEA is an evidence-based analysis of social and environmental issues within the context of strategic planning. SEAs assess the impacts of risks and the costs of mitigation actions and include a quantitative analysis of social and environmental impacts, with economic valuation where possible. SEAs present scenarios with feasible alternative development options that lead to the desired planning outcomes. They integrate social and environmental factors (e.g., resettlement and greenhouse gas emissions) that have traditionally been treated as externalities in preparing PDPs, and then internalize these values into an overall economic assessment of development plans.

The integration of an SEA in the preparation of PDPs reflects $V$ iet Nam's national development approaches in documents such as the Socio-Economic Development Plans, and the Green Growth Strategy and Climate Change commitments, which require the inclusion of social and environmental impacts in plan preparation. SEAs have been mandatory for strategic plans since the 2005 Law on Environmental Protection was passed and the power sector was identified as a key sector for the early implementation of this provision. The inclusion of an SEA has meant that the PDP is better aligned with national policies, particularly in 
the energy sector, and can more effectively reflect specific national targets in areas such as renewable energy and greenhouse gas (GHG) mitigation.

The first integration of SEA into the PDP in Viet Nam was done in the preparation of the Hydropower Master Plan in the context of PDP VI. This pilot SEA considered the potential impacts of the 21 large-scale hydropower schemes included in PDP VI. Five scenarios were considered: one with a base case consisting of the existing schemes included in PDP VI, and four that progressively reduced the number of hydropower schemes and replaced them with the least-cost alternatives (generally thermal power) identified through the PDP process. The impacts of the alternative generating sources were considered in each scenario, providing a meaningful analysis of the different options to meet the needs for generation capacity defined in PDP VI.

The study demonstrated the potential of SEA as an integral component of strategic planning for the hydropower sector in Viet Nam. It provided, for the first time, a mechanism to analyze hydropower's potential impacts on people and the environment within and beyond the immediate vicinity of hydropower construction. It also provided a mechanism to identify and assess appropriate mitigation and compensation measures, including actions to reduce risks and compensate for any negative impacts.

The lessons learned from the pilot SEA showed that changes were needed in the PDP planning process to ensure that social and environmental impacts were fully integrated into the plans for the sector. A detailed model of how to achieve this was advanced in the final chapter of the study. This model was used to inform the development of the SEA in PDP VII, which was based on the experiences and capacities developed in the execution of the pilot hydropower SEA linked to PDP VI.

The original PDP VII was prepared in 2011-2012 to guide the development of the power sector for the period 2011-2030. It analyzed future electricity demand scenarios by sector, taking into account potential economic and social development trends. It also assessed the most effective, least-cost power generation options for meeting likely future demand patterns. The plan's SEA was done simultaneously with the preparation of the PDP. While there was close coordination at the different stages of analysis during the PDP and the SEA preparation, there were also limitations in the extent to which the SEA was fully integrated into the PDP process.

The SEA of the original PDP VII in 2012 assessed all social and environmental impacts and found that the largest potential impact was atmospheric pollution from thermal power stations, especially coal. The forecast showed:

(i) GHG emissions. Carbon dioxide $\left(\mathrm{CO}_{2}\right)$ impacts were valued at $\$ 1.2$ billion in 2011, which could reach more than $\$ 9$ billion by 2030 .

(ii) Acidification. Sulfur dioxide $\left(\mathrm{SO}_{2}\right)$ impacts were valued at $\$ 94$ million in 2011 , which could reach more than $\$ 728$ million by 2030 .

(iii) Health. Particulate matter and nitrogen oxides $\left(\mathrm{NO}_{x}\right)$ impacts were valued at $\$ 330$ million in 2011, which could reach $\$ 1.35$ billion by 2030 . 
Awareness of these impacts and concerns that the demand projections were too high led to a revision of PDP VII. The preparation of the revised PDP was based on the SEA from the original plan, with the scenarios in the analysis defined in relation to impacts identified in the SEA and related to the achievement of policies on renewable energy and energy efficiency. During the plan's revision, the proportion of renewable energy was increased sevenfold and the amount of coal-fired power generation was decreased by $30 \%$, in response to government requirements to reduce air pollution impacts. The revised version was approved in 2016. The changes will reduce GHG emissions by 100 million tons of $\mathrm{CO}_{2}$ $\left(\mathrm{tCO}_{2}\right)$ per year by 2030 from the original PDP VII base case. In terms of economic value, this represents savings of about $\$ 1$ billion a year, based on the price of $\$ 10$ per $\mathrm{tCO}_{2}$ used in the revised PDP VII.

The development of the SEAs in the PDP system in Viet Nam represents an evolution from the original SEA of PDP VI, which focused on hydropower and was executed when the PDP was completed. The SEA in the original PDP VII was conducted at the same time as the main planning exercise but was not fully integrated into it. Ultimately, the SEA was integrated into the RPDP VII and helped to define the overall plan. This evolution of SEAs in the PDP process has brought considerable benefits, although a number of challenges remain before Viet Nam can be said to have a fully developed PDP with SEA process. These challenges relate to the following:

(i) Improving the power system modelling programs used in the PDP needs to reflect the shift in focus from conventional large-scale generation options to a more diversified portfolio of activities in the plan, along with the inclusion of relevant environmental and social costs and benefits.

(ii) Improving the input database for power system modelling comes with a detailed definition of cost of investments, and externalities and related benefits. This development of the database will ensure that the cost calculations of future PDPs can accurately reflect the full economic costs to Viet Nam's economy and society of the different power generation options considered in the plan.

(iii) Improving the relationship between the national-level power sector planning process and provincial-level planning process, especially in the development of renewable energy sources such as solar, wind, biomass, and small hydropower plants, is important. The preparation of related SEAs at the provincial level must be improved as well to reflect the policy that provinces are responsible for the planning of power generation facilities smaller than 30 megawatts (MW). At present, few provinces have the capacity to plan such investments in an effective manner that takes account of the full range of economic, social, and environmental costs involved.

These challenges suggest that, notwithstanding the significant progress made in recent PDP cycles, there is a need to improve the PDP process to fully integrate SEAs. This means that the Ministry of Industry and Trade as the responsible government agency should act to ensure the preparation of a methodological and procedural framework for a PDP that (i) addresses the abovementioned challenges and thus, fully integrates SEA into PDP, and (ii) consistently reflects Vietnamese legislation and government procedures. Recent changes in legislation, such as the new Law on Planning and laws relating to decentralization, must be reflected in any changes to the PDP preparation process. Such updates can also be used 
to see which Vietnamese institutions need to build their capacities. Should this next step in the evolution of the PDP process in Viet Nam be put in place, then the country can become an international model of good practice in modern power sector planning, taking account of all social and environmental impacts and taking advantage of opportunities that will be presented by the changing nature of energy technologies and markets in the coming years.

The next PDP VIII, which is being prepared for approval in 2020-2021, will be a great opportunity to reflect all the required changes and demonstrate suggested improvements. 


\section{Introduction}

\subsection{Purpose and Rationale for the Report}

This document lays out the experience of Viet $\mathrm{Nam}$ in the integration of a Strategic Environmental Assessment (SEA) into the preparation of the country's Power Development Plan (PDP). It traces the evolution of the process of integrating an SEA into strategic planning, either in the sector leverl or the national level, from having no experience with SEA integration to having the SEA fully integrated into the PDP process. The latest version of the PDP-the revised PDP VII (RPDP VII) - can now be seen as a model of good practice in integrating an SEA in the preparation of a strategic plan that is important not just for Viet Nam but for the power sector of other countries, particularly in the Greater Mekong Subregion (GMS). This did not happen overnight. The full integration of the SEA went through several iterations and was accompanied by the development of capacities and impact assessment methodologies. The inclusion of the SEA has provided a better understanding of the implications of the different development options in the PDP, resulting in significant changes to the final contents of the plan and ensuring the alignment of the PDP with the overall national development policies of Viet Nam. This shows how an SEA, when fully integrated into the strategic planning process, will result in better plans that are based on a more thorough understanding of the plan's implications for the economy, society, and environment of the country.

One of the main objectives of TA 9003 is to capture the experiences of Viet Nam in integrating an SEA into its PDP preparation to provide lessons for other GMS countries that are in the early stages of this process. The Vietnamese experience reflects ADB support to SEA integration in the PDP that has been in place for over a decade, with the present TA building on sustained support provided through ADB's GMS program. The outcomes of this support are laid out in this report. Great progress has been made but there is a need for the continuing development of the PDP process so it can take advantage of technological innovations and rapid changes in the international energy markets. With the progress in SEA development, the foundation for these changes has been laid and the progressive improvement of power sector planning in Viet Nam can be expected.

\subsection{Strategic Environmental Assessment}

If the 1972 Stockholm Conference on the Human Environment can be considered the official start of international environmental awareness, then the 1992 Rio Earth Summit (the United Nations Conference on Environment and Development) represented a partial "coming of age" of the international environmental movement. Environmental issues are 
increasingly recognized as being fundamental not just to social and ecosystem well-being but to sustainable economic development as well. The links between improved environmental management and economic development were at the core of the UN conference agenda. ${ }^{1}$ Governments recognized the need to redirect international and national plans and policies to ensure that all economic decisions took into account any environmental impacts.

Environmental concerns and management have also shifted from being seen as rich-country problems (for their role in impacting the environment through industrial activities) to problems that are important to all nations-rich and poor alike. Governments in developing countries have become increasingly aware that environmental and natural resource degradation endangers the potential for long-term development. As a result, they are more receptive to the implementation of measures which ensure that development projects take both the environment and natural resources into account.

A report by the World Commission on Environment and Development titled "Our Common Future," also known as The Brundtland Report in honor of the commission chair at that time, put to the fore the concept of sustainable development. The idea that sustainable development means "meeting the needs of the present generation without compromising the needs of future generations" explicitly recognizes the limited nature of environmental resources, inter-generational equity issues, and the need to evaluate trade-offs for the current generation, as well as between resource use and environmental quality now and in the future (footnote 1).

SEA is a tool to assist decision-makers in considering the benefits and impacts of proposed development policies, strategies, or plans in a more comprehensive manner; in other words, to assess the sustainability consequences of such development. It is the evidence-based analysis of the social and environmental implications of proposals put forward within a strategic plan. It aims to present a balanced assessment that will help stakeholders establish a consensus on the most effective planning outcome. SEA has been defined as follows: ${ }^{2}$

"SEA is a process directed at providing the authority responsible for policy development and the decision-maker with a holistic understanding of the environment, social and economic implications of the policy proposal, expanding the focus well beyond what were the original driving forces for new policy."

As ADB points out, an SEA differs in structure and purpose from an environmental impact assessment (EIA): "SEA is a tool to help policy makers integrate the environmental, social and economic dimensions of sustainability into decision-making. SEA is different from EIA, which assesses the impacts of projects."3 Some key differences between SEAs and EIAs are (i) SEAs are done earlier in the planning process as an integral part of strategic planning, while EIAs are usually conducted after detailed plans for the proposed project have been prepared; (ii) SEAs cover a whole sector (such as the power sector), a region, or even an entire country, and often span long periods, whereas EIAs are for individual projects and provide, in effect, a snapshot of one plan at a time; and (iii) SEAs take into

J. Dixon. 1994. Economic Analysis of Environmental Impacts. London. Earthscan/ADB/IBRD.

2 A. Brown and R. Therivel. 2000. Principles to Guide the Development of SEA methodology. Impact Assessment and Project Appraisal, 18(3). pp. 183-190.

3 ADB. 2015. Integrating Strategic Environmental Assessment into Power Planning. Manila. p. 6. 
account all the potential impacts of planning proposals, while EIAs usually look only at the direct impacts of the plan where it is to be implemented. As the Organisation for Economic Co-operation and Development (OECD) noted, "the environmental effects associated with policy reforms are often indirect, occur gradually over the long term and are difficult to assess accurately. ${ }^{4}$ While still very valuable and relevant at the project level, established EIA procedures, methods and techniques have only limited application at the level of policies, plans and programs." The OECD report provides a clear summary of the differences between SEAs and EIAs (Table 1).

\section{Table 1: Comparison of Environmental Impact Assessment and Strategic Environmental Assessment}

\begin{tabular}{|c|c|}
\hline Environmental Impact Assessment & Strategic Environmental Assessment \\
\hline $\begin{array}{l}\text { Applied to specific and relatively short-term } \\
\text { (life cycle) projects and their specifications }\end{array}$ & $\begin{array}{l}\text { Applied to policies, plans and programs with a } \\
\text { broad and long-term strategic perspective }\end{array}$ \\
\hline $\begin{array}{l}\text { Takes place at the early stage of project } \\
\text { planning once parameters are set }\end{array}$ & $\begin{array}{l}\text { Ideally, takes place at an early stage in strategic } \\
\text { planning }\end{array}$ \\
\hline Considers limited range of project alternatives. & Considers a broad range of alternative scenarios \\
\hline $\begin{array}{l}\text { Focuses on obtaining project permission, and } \\
\text { rarely with feedback to policy, plan, or program } \\
\text { consideration }\end{array}$ & $\begin{array}{l}\text { Focuses on decision on policy, plan, and } \\
\text { program implications for future lower-level } \\
\text { decisions }\end{array}$ \\
\hline $\begin{array}{l}\text { Well-defined, linear process with clear } \\
\text { beginning and end (e.g., from feasibility to } \\
\text { project approval) }\end{array}$ & $\begin{array}{l}\text { Multistage, iterative process with feedback } \\
\text { loops }\end{array}$ \\
\hline $\begin{array}{l}\text { Preparation of an environmental impact } \\
\text { assessment document with prescribed format } \\
\text { and contents is usually mandatory. This } \\
\text { document provides a baseline reference for } \\
\text { monitoring }\end{array}$ & May not be formally documented \\
\hline $\begin{array}{l}\text { Emphasis on mitigating environmental and } \\
\text { social impacts of a specific project, but with } \\
\text { identification of some project opportunities, } \\
\text { offsets, etc. }\end{array}$ & $\begin{array}{l}\text { Emphasis on meeting balanced environmental, } \\
\text { social, and economic objectives in policies, } \\
\text { plans, and programs; Includes identifying } \\
\text { macro-level development outcomes }\end{array}$ \\
\hline $\begin{array}{l}\text { Limited review of cumulative impacts, often } \\
\text { limited to phases of a specific project. Does not } \\
\text { cover regional-scale developments or multiple } \\
\text { project }\end{array}$ & $\begin{array}{l}\text { Inherently incorporates consideration of } \\
\text { cumulative impacts }\end{array}$ \\
\hline
\end{tabular}

Source: OECD. 2006. Applying Strategic Environmental Assessment. Paris. p. 32.

As an approach, SEAs have been around for some time but they are increasingly being used as a formal part of and, in many cases, a legal requirement for strategic planning processes by government agencies for key investment and development sectors, such as energy and power generation. The advantages of an SEA as part of the strategic planning process are now more appreciated. Many countries are implementing legislation to make it a compulsory part of strategic planning. This is true in the GMS region, where all six member countries either

4 OECD. 2006. Applying Strategic Environmental Assessment. Paris. p. 24. 
already have or are in the process of passing legislation to require the use of SEA within strategic planning.

Although there are many examples of the use of SEA independently from strategic planning, this is not the reason the approach was developed: "The main purpose of SEA is to facilitate early and systematic consideration of potential environmental impacts in strategic decision-

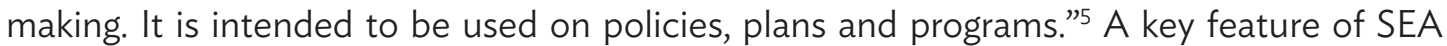
within a strategic planning context is that it is not a separate exercise but is structured into the strategic planning system. This means the plan methodology must adapt to integrate an SEA into the plan preparation. It is through this change in the planning system that the full benefits of an SEA will be realized.

There are different SEA methodologies: some have six stages while others may have seven or more. But all share certain characteristics. The SEA for a strategic plan should predict the potential positive and negative impacts of the different planning options, and evaluate whether these impacts are significant enough to need mitigation actions that will reduce the negative and enhance the positive impacts.

One of the main methods used to do this analysis is scenarios, which allow the examination of the costs and benefits of different planning options. For example, in power sector planning, scenarios can be built from the different mixes of generation types (thermal, hydropower, renewable energy) or different levels of future demand for electricity. Scenarios provide a better understanding of the complete picture when there is uncertainty over the future state or value of key variables such as the cost of generating electricity from different sources. They are also used to internalize (include in the cost calculations) social and environmental impacts, such as GHG emissions or loss of forest cover, which have traditionally been treated as externalities and hence, left out of cost calculations. Using scenarios, alternative development options can be thoroughly considered and compared, and sensitivity analysis applied where it is possible to assess the implications of changes to key assumptions such as future fuel prices, climate change, or capital discount rates.

The comprehensive and systematic character of SEA provides a structure for the economic valuation and integration of factors that have been traditionally treated as externalities, ${ }^{6}$ leading to a better understanding of the full economic costs and benefits of different planning options. Such characteristics of an SEA, when integrated into the PDP process, will paint a clearer picture of the implications of different plan choices and aid decision-making with the use of comprehensive evidence. An SEA will complete strategic planning and make it more effective. The additional effort this may require at the planning stage is more than compensated for by quicker, less contentious, and better decisions.

G. Finnvedan. et al. 2002. Strategic Environmental Assessment Methodologies: Applications within the Energy Sector. Environmental Impact Assessment Review 23(2003). pp. 91-123.

6 The World Bank Handbook on Economic Analysis of Investment Operations (1996) defines externalities as (i) the difference between the benefits (costs) that accrue to society and the benefits (costs) that accrue to the project entity, and (ii) the "activities generating benefits and costs that are not reflected in the benefits and costs of the firm" (p. 39) 


\subsection{Summary of Traditional Power Development Plan Systems}

\subsubsection{Institutional Responsibilities for Power Development Plans}

Until recently, the General Directorate for Energy (GDE) of the Ministry of Industry and Trade (MOIT) was responsible for preparing the PDPs for Viet Nam's power sector. After the restructuring, the responsibility was passed on to the Electricity and Renewable Energy Authority. In the past, the GDE commissioned the Institute of Energy, a scientific and technological research agency under the MOIT, to prepare the PDP. Before 1995, the institute was under the Ministry of Energy, and between 1995 and 2010, it was part of Vietnam Electricity (EVN). The Institute of Energy operates in closely related fields, including:

(i) national energy and electricity development, strategic planning, and policy and planning;

(ii) science and technology of energy electricity, environment, and energy development;

(iii) scientific and technological consultancy and services; and

(iv) training human resources, and scientific and technological cooperation with domestic organizations, foreign organizations, and other enterprises.

One of the institute's principal undertakings is the preparation of the master plan for energy and power development, i.e., the PDP.

PDPs are the national strategic development plans for power production and utilization in Viet Nam. Introduced in the 1980s, PDPs originally had a five-year duration, reflecting the overall planning system in the country, which works to five-year plans for all sectors. The scope and timing of PDPs were adjusted in 2012 under Law No. 24/2012/QH13, "Amending and Supplementing a Number of Articles of the Electricity Law," which changed the PDP coverage to 10 years, with a revision after 5 years based on social and environmental issues. The most recent manifestations of the PDP have been:

(i) PDP VII Revised (Decision 428/QD-TTg approved in March 2016),

(ii) PDP VII (Decision 1208/QD-TTg approved in July 2011), and

(iii) PDP VI (approved in 2005).

The 2005 Law on Environmental Protection requires all strategic plans, including PDPs, to incorporate an SEA as part of their preparation. This requirement has led to the gradual modification of the PDP process to integrate the elements of an SEA into it.

\subsubsection{Power Development Plan Methodology}

As noted earlier, the mandatory SEA for the PDP is relatively new in Viet Nam. The PDP and the SEA are prepared separately by the Institute of Energy (the nominated planning consultant): the planning team compiles the PDP report and the SEA team prepares the 
SEA report. The format and contents of both documents must comply with the regulations in specific legal documents.

The 2005 Law on Environmental Protection made it clear that the scope of an SEA should include social development issues, as well as issues related to environmental protection and resource management. The new 2014 Law on Environmental Protection (No. 55/2014/ $\mathrm{QH} 13$ ) outlines the content scope and responsibilities related to the SEA preparation. This is discussed in section 2.2 on Origin and Policies for SEA in Viet Nam.

Circular 43/2013/BCT prescribes a report structure to cover a range of issues and lays down procedures for the formulation, assessment, and approval of the national PDP. These steps define the roles and responsibilities of the different institutions involved in the preparation and approval of the PDP. The core of this process is the relationship between the MOIT, as the agency with overall responsibility, the Institute of Energy as the agency commissioned to prepare the PDP, and other organizations involved in the review and approval of the PDP.

The approach to PDP preparation has evolved over time, with the earlier PDPs being based almost exclusively on technical and financial criteria. In the past, a least-cost approach was used and only direct financial costs were considered in identifying the best mix of investments in generating capacity and developing the power transmission system. With the introduction of the SEA into plan preparation, a more comprehensive consideration of social and environmental issues was included in the PDP. The wider policy context has also changed, with a shift at the national level from an emphasis on economic growth to a development approach that puts economic, social, and environmental development and sustainability at the heart of national development.

\section{Power Development Plan Contents, Formulation, Assessment, and Approval Procedures}

The preparation of the PDP starts with a review of the current conditions of the national electricity system and proceeds with an assessment of the performance of national electricity development planning in the previous PDP period to see if the predicted expansion of generation capacity and the transmission system had been achieved. This assessment has shown that several factors limit the effectiveness of PDP implementation. These include incorrect demand growth forecast, delays associated with financing and variations in project costings, land acquisition, legal objections, and the resettlement of displaced communities.

The PDP examines the factors that will influence future demand for electricity: patterns of socioeconomic development, sectoral economic growth, and changing patterns of consumption. Viet Nam, along with other GMS countries, has shown strong industrial growth and increasing household incomes in recent decades. A successful electrification program has resulted in a nearly universal access to electricity throughout the country. These factors are considered when defining the input parameters and criteria for planning. Key input parameters include those relating to load forecasting, such as price and income elasticities, gross domestic product (GDP) growth, system losses, electrification rates, and system security. The loss of load probability or loss of load expectation, which can be used by the generation expansion software, can help establish an economic optimum level of security. 
These parameters help generate demand forecasts which are disaggregated by province, region, and sectors. The resultant forecasts are sensitive to location-specific industrial development, settlement growth, and other factors. The demand forecasts themselves have historically been strongly affected by economic growth forecasts, which have been high in the past decades.

The PDP then focuses on the supply side, with an assessment of primary energy sources available to Viet Nam. Consideration is given to primary energy exploitability as well as the potential importation and exportation of energy. Viet Nam has three very distinct regionsNorth, Central, and South-with equally distinct primary energy resources: coal in the north, hydropower in central, and natural gas in the south. The law stipulates an assessment of the exchange of electricity between regions. Forecasts of fuel prices for electricity production are critical in this section. For example, the importation of high-grade coal may be of interest, but the price may be more volatile than domestic coal production.

Following these preparatorysections, the main body of the PDP is concerned with the country's large electricity source development program. The nation's installed capacity is substantialin excess of 40,000 MW-and demand is growing rapidly due to industrialization and general economic growth. So as not to jeopardize this rapid economic expansion, the country has to ensure that its installed generation capacity can keep up with the growth in demand. Until recently, satisfying the expansion of generating capacity has been focused almost exclusively on large, conventional generation projects such as gas-fired Combined Cycle Gas Turbine, coal-fired steam, and large hydro. The basis for the identification of the mix of investments in generation expansion had been the least financial cost: essentially, preference has been given to generation options that were cheapest in terms of initial investment and lifetime operational costs.

In recent years, Viet Nam has entered into international commitments to control GHG emissions and, as a consequence, has made great strides to alter the future mix of its generation plant portfolio to include more renewable energy. As the PDP process evolved, the main mechanism that examines the potential social and environmental impacts of the plan's implementation falls within the framework of the SEA that is now a legal requirement.

The electricity transmission system development is an important element of any PDP. The physical geography of the country makes transmission development technically challenging. The PDP provides a detailed plan for transmission development at the 500 kilovolt (kV) and $220 \mathrm{kV}$ levels at both national and regional levels. The PDP also considers the expansion of the distribution grid (i.e., $110 \mathrm{kV}$, medium- and low-voltage).

Historically, interconnecting the national grid with neighboring countries has not been a national priority. Until very recently, Viet Nam's trans-boundary interconnections were limited to relatively small interconnections with the People's Republic of China and Cambodia, and a project-specific interconnection with the Lao People's Democratic Republic (Lao PDR) to import from a hydro project. Recently, however, Viet Nam has signed a memorandum of understanding with the Lao PDR to develop interconnections totalling $2,000 \mathrm{MW}$ by $2020,3,000 \mathrm{MW}$ by 2025 , and $5,000 \mathrm{MW}$ by 2030 . As all the national power systems in the GMS have expanded rapidly, the merits of cross-border cooperation have become increasingly prominent, and it is possible that the recent agreement with the Lao PDR will be followed by other such agreements. 
The teams preparing the plan for transmission development are required to collect suggestions from the People's Committees of Viet Nam's provinces on the locations of power plants and $500 \mathrm{kV}$ substations. Consultations to consider the implications of potential social and environmental impacts are also necessary. To date, this has principally involved provincial authorities, although some attempts to consult with civil society organizations have also taken place.

Further consultation with key stakeholders takes place after the draft PDP is completed. The plan is submitted to Vietnam Electricity (EVN), Vietnam National Oil and Gas Group, Vietnam National Coal-Mineral Industry Holding Corporation Limited, regional power corporations, and the National Power Transmission Corporation for comments and completion before it is sent to the GDE for assessment, and subsequently to the MOIT for review and submission to the Prime Minister, who will give the final approval.

During the review process, the MOIT forms an Assessment Committee and collects the views of concerned ministries, departments, and other organizations on the draft PDP. At the same time, the SEA report is submitted to the Ministry of Natural Resources and Environment for review and approval. If any comments received during these review processes (the overall PDP and the SEA) necessitate further consideration of the plan's proposals, the plan is returned to the team that prepared it for further analysis. Another iteration of the review process takes place. When finally, all parties are satisfied with the draft plan, it is submitted to the Prime Minister for formal approval, along with a presentation of a decision that outlines the main proposals of the plan.

\section{Shortcomings of the Current Power Development Plan Preparation Methodology}

The development of the PDP in Viet Nam has evolved in recent iterations of the planning process but despite this, senior planners at the Institute of Energy believe more work is needed to come up with an approach that is fully in line with the needs of the country as the economy and policy framework of the country develops.

For one, there has been insufficient consideration of energy efficiency and demand-side management programs that could have a substantial impact on the rate of growth of demand or the energy intensity of the economy. This was true even in the preparation of PDP VII. There have been studies and programs on energy efficiency, often done with support from international development partners, but their possible contributions to PDP preparation have not been fully structured into the process.

The power demand forecasts have also not been accurate, with the patterns of demand diverging from predictions in the plan. This is true for both the total demand over time and the sectoral and regional patterns of demand. Improvements in the PDP process must include more sophisticated and effective demand forecasting methods.

The extent of interaction between the preparation of the main PDP and the development of the SEA had not been strong, but it is improving over time. The Institute of Energy is making changes to PDP preparation to fully integrate the SEA into the overall PDP process.

Another thing that needs a closer look is the integration of the power sector planning systems of Viet Nam and its neighbors so that planners can assess the full range of cross- 
border trading opportunities. Right now, power imports are modelled as importing sources from neighboring countries, but there is no modelling undertaken of the systems of these countries, which means little is known about the future availability or cost of power imports. The country's planners merely work with assumptions.

The existing Vietnamese interconnection ratio of $3 \%$ is relatively low and will be reduced by a factor of three from now to the end of RPDP VII. This trend is clearly not in line with GMS regional studies, which found that Viet Nam and its neighbors will greatly benefit from a higher level of interconnection and cross-border trade in the region.

To date, the development of scenarios in the PDPs have concentrated on the technical and financial aspects of the expansion options, although, again, this is improving over time. The scenarios used in the RPDP VII represent a significant breakthrough in this regard, but more work is needed to strengthen the economic analysis of social and environmental issues in the scenarios of future PDPs.

There have been concerns that the level of coordination between the PDP and the SEA approval processes should be improved as they have largely taken place parallel to each other. The range of consultations at each stage of the PDP preparation and review must be expanded because at present, consultations are largely confined to directly concerned government agencies (the same is true for the SEA process). These and other areas, such as the PDP monitoring and evaluation system, need to be strengthened as part of the wider process of power sector planning reform and enhancement.

There is a recognition of the need to improve the scope of and methods used in the PDP preparation in Viet Nam. In a number of cases, the need for these improvements has been recognized partly because of the steps taken to integrate the SEA more effectively into PDP preparation. 


\section{Context}

\subsection{Understanding the Need to Change Power Sector Planning}

The evolution over the last decade or so of strategic planning of the power sector-which now includes social and environmental issues as an integral part of the process-reflects a series of changes in the wider policy and institutional environment of contemporary Viet Nam. Expectations on the character of power sector planning have gone through a transition: from being seen exclusively in terms of its ability to expand rapidly at the lowest financial costs, to reflecting the sustainable development aspirations of the country. These bigger aspirations reflect the changing perspectives on the nature of development in Viet Nam and are enshrined in key policy and legislative developments in the last 10-12 years.

The understanding of the need to move from the growth-at-any-cost approach to a balanced and sustainable pattern of economic and social development has progressed. This reflects emerging internal concerns over issues such as water and air pollution, deforestation and wider ecosystems degradation, and a desire to avoid the negative experiences of other countries. Viet Nam's participation in regional and international development bodies, such as the United Nations Framework Convention on Climate Change (UNFCCC) and the Association of Southeast Asian Nations, reinforced this shift in perspective. The country's leadership is now working to meet international commitments and to ensure that Viet Nam's development is more sustainable.

Viet Nam's national development approaches are defined in the national Socio-Economic Development Plan (SEDP), which sets key goals and targets for a five-year period. An earlier emphasis on economic growth as the prime objective was replaced by a strategic planning approach that balances economic development, social equity, and environmental sustainability. This was first enshrined in the goals of the 2006-2010 SEDP and the Viet Nam 2020 Vision, which represented a significant shift in the national development aspirations. These principles were carried over to the 2011-2015 SEDP, which incorporated new regulations and decrees on different aspects of sustainable development and environmental protection. These include measures to ensure reasonable, effective, and sustainable use of natural resource; reduction of water and air pollution; expansion of forest coverage; and the integration of climate change into strategic planning and natural resource management.

The 2016-2020 SEDP, approved by the National Assembly of Viet Nam under Resolution No. 142/2016/QH13 on 12 April 2016, reinforced and deepened this approach. This SEDP emphasized the need for economic restructuring to achieve a balanced and sustainable economic growth. It underscored the need to "actively respond to climate change, effectively 
manage resources and protect the environment" (Article II.1). The SEDP highlights the need to improve the quality of infrastructure planning, particularly for the power sector, so it aligns with the national development approach laid out in the plan. The SEDP includes an expectation for economic growth to be in the range of $6.5 \%-7 \%$ per year during the plan period. A $1 \%-1.5 \%$ per year decrease in energy consumption per unit of GDP is also included in the SEDP as a "major economic target" (Article II.2.1). It supports the development of renewable energy sources "economically, efficiently and environmentally friendly" (Article III.6) but does not set specific targets (reflecting the existence of targets in the 2015 Renewable Energy Decision).

This balanced approach to development in Viet Nam, which can no longer be considered new and is the established national orthodoxy, is expected to continue and be reflected in all strategic plans. It is increasingly seen in sector-specific policies and legislation, even for the power sector.

\subsection{Origins and Policies for Strategic Environmental Assessment}

Viet Nam was one of the first countries in the Asia Pacific region to pass legislation mandating the use of Strategic Environmental Assessment (SEA) in strategic planning. The legislative requirement for the Power Development Plan (PDP) to include an SEA stems from the 2005 Law on Environmental Protection (LEP), which makes it clear that the scope of an SEA shall include social development issues as well as issues related to environmental protection and resource management. The 2005 LEP also covered the growth of renewable energy, protection of river basins, and the maintenance of environmental standards in relation to production investments. This was an innovative step at the time, done with an awareness that capacities and detailed procedures must first be developed before the provision in the law could be implemented. While it clearly would not happen overnight, the introduction of SEA in strategic planning was an important step that had to be made with a clear legislative basis.

The responsibility in SEA report preparation is defined in Decree 140/2006/ND-CP (22 November 2006), ${ }^{7}$ which defines the roles of ministries responsible for environmental protection during the drafting, approval, and implementation of a development strategy or plan. Decree 140 identifies the Ministry of Natural Resources and Environment as the agency responsible for the monitoring, review, and approval of SEAs, while the task of conducting the SEAs falls on the agency undertaking the planning exercise, i.e., the Ministry of Industry and Trade (MOIT) for the PDPs.

The role of SEAs in strategic planning was further emphasized in Decision 1216, "Approving the strategy for protecting the national environment by 2020 and the orientation towards 2030," which was approved on 5 September 2012. This decision updated and expounded on certain provisions of the 2005 LEP, stating the need to "enhance the quality of Strategic Environmental Assessment, satisfying the requirements for environmental protection

Government of Viet Nam. Decree 140/2006/ND-CP Providing for the Environmental protection at stages of elaboration, evaluation, approval and implementation of development strategies, plannings, plans, programs and projects. Ha Noi. 
included in the strategies, planning, plans, programs and schemes for socioeconomic development." 8

The 2005 LEP was replaced in 2014 by the Law on Environmental Protection. ${ }^{9}$ Article 3, paragraph 22 of the 2014 LEP gives a clear definition of SEA for Viet Nam: "Strategic environmental assessment refers to the analysis and forecast of existing or potential impacts on the environment, which have been described in the development strategy, planning and proposal, in order to provide measures to control and reduce adverse impacts on the environment, and to serve as a ground for and to be incorporated in such development strategy, planning and proposal with the objective of ensuring the sustainable development."

Chapter 2 Section 2 of the 2014 LEP provides considerable detail on the objectives, contents, and responsibilities for the implementation of SEAs, granting a better understanding of the role of SEAs in strategic planning in Viet Nam. It specifies when an SEA should be conducted and lists all key sectors, administrative areas (in relation to their development plans), and specialized areas such as economic corridors and industrial zones. In Article 14, it reiterates that responsibility for the preparation of the SEA lies with the agency preparing the plan and states, crucially, that "the SEA must be carried out simultaneously with the process for preparing the strategy" and that "the final result of the SEA must be checked and incorporated into the strategy."

The 2014 LEP details the contents, scope, and responsibilities at different stages of conducting and reviewing the SEA report. As such, the 2014 LEP cements the role of SEA in strategic planning in Viet Nam and addresses concerns over the different aspects of SEA implementation that had emerged from earlier legislation. It also recognizes the SEA as an important tool in improving the planning process. Decree No. 18/2015/ND-CP on environmental protection planning, strategic environmental assessment, environmental impact assessment (EIA), and environmental protection plans, issued by the Government of Viet Nam on 14 February 2015, developed the system further by defining in detail the issues that must be studied when preparing the SEA report, as well as the EIA and Environmental Protection Plans.

\subsection{Wider Policy Context}

In addition to the overall national development approach reflected in the SEDPs and the specific legislation on SEAs in the LEP and other directives, there are a number of further laws, policies, and strategies that must be considered when conducting a power sector strategic plan that integrates an SEA. These additional documents fall into two categories: those related to the general development context of the country and those that are specifically related to developments in the power sector. The definition of the scope and objectives of the PDP, and of the SEA within it, needs to take into account the priorities and targets laid out in this range of policies and legislation. This can be general, such as setting an overall objective to minimize ecosystems degradation in power sector development, or it can be

8 Government of Viet Nam. Prime Minister's Decision No. 1216/QD-TTg Approving the strategy for protecting the national environment by 2020 and the orientation towards 2030. Ha Noi.

9 Government of Viet Nam. The National Assembly. Law No. 55/2014/QH13 Law on Environmental Protection. Ha Noi, 23 June 2014 
specific, such as meeting defined targets for renewable energy or the maximum levels of emissions from power generation. The documentation of the PDP and the SEA needs to have a detailed discussion on how these wider policy agendas are addressed in the strategic planning process.

\subsubsection{Overall Development Policies}

The process of reform and re-direction of approaches to and priorities in national development have resulted in several key policy and strategy documents in recent years. Two of the important strategy documents approved in 2012 are: (i) Decision No. 432/QDTTg, approved on 12 April 2012, on the Approval of the Sustainable Development Strategy of Viet Nam for the period 2011-2020; and (ii) Decision No. 1393/QD-TTg, approved on 25 September 2012, the Approval of the National Strategy on Green Growth.

The Sustainable Development Strategy of Viet Nam for the period 2011-2020 adopts the approach from the SEDPs, which seeks to balance economic growth with social development and environmental sustainability. It specifies that all development planning must consider these three issues and prioritize long-term development approaches. It specifies development indicators that are directly relevant to the preparation of a PDP: (i) the reduction of energy consumption to produce a unit of GDP, (ii) the percentage of renewable energy in power generation, (iii) the reduction of the loss of forest cover and ecosystems degradation, (iv) the reduction in water pollution and water resources degradation, and (v) the reduction in air pollution. The strategy specifies that a green growth approach, including low-carbon development, is the priority for future national development and must be taken into account in all aspects of development planning. This includes a commitment to "increasing the proportion of clean and renewable energy in total energy consumption in Viet Nam" (page 4 of the English translation).

These provisions are echoed in the National Strategy on Green Growth, which prioritizes the use of technologies that will ensure greater efficiency in resource use and the minimization of greenhouse gas (GHG) emissions. This includes specific targets that are relevant to the development of a PDP:

"Reducing the intensity of greenhouse gas emissions and boosting the use of clean energy, renewable energy according to the following main criteria:

Period 2011-2020: Reducing greenhouse gas emissions intensity by $8 \%-10 \%$ compared to 2010 , reducing energy consumption on GDP by $1 \%-1.5 \%$ per year. Reducing greenhouse gas emissions in the energy activity from $10 \%$ to $20 \%$ compared with the normal development plan in which the voluntary level of about $10 \%$, the remaining $10 \%$ of striving level upon having more international support.

Orientation to 2030: Reducing greenhouse gas emissions each year by at least 1.5\%$2 \%$, reducing greenhouse gas emissions in the energy activities from $20 \%$ to $30 \%$ compared with the normal development plan in which the voluntary level is about $20 \%$, the remaining $10 \%$ is the level upon international support (Section II.1)." 
The strategy goes on to emphasize the need to improve energy efficiency in transport, industry, and commercial activities, and the need to ensure a transition from dependence on fossil fuels to the use of new and renewable energy resources.

The 2014 Law on Environmental Protection (LEP), in addition to the clauses on SEA discussed above, includes provisions concerning the energy sector. It prioritizes energy efficiency and promotes the development of "green and renewable energy" both for the overall effectiveness of national development and as a means to respond to climate change and reduce GHG emissions. This is reflected in Article 43 on renewable energy development, which stipulates the need to "promote the production, importation and employment of renewable energy-driven machinery, equipment and means of transport."

There are a number of documents related to climate change that are relevant to the development of power sector planning in Viet $\mathrm{Nam}$. The government introduced the National Target Program to Respond to Climate Change (NTP) on 2 December 2008 (Decision 158/2008). This recognized the importance of climate change as a strategic issue for the country and defined a program up to 2015 to assess and define responses to existing and potential climate change impacts. The NTP does not contain specific activities on the power sector but it does define the need to "mainstream climate change into development plans" such as the PDPs. The NTP has also, since 2008, provided a framework for considerable assistance from international development partners such as Danida, Asian Development Bank (ADB), and others in climate change assessment, planning, and adaptation activities for different parts of the country.

The National Strategy on Climate Change (Decision 2139, dated 5 December 2011) recognizes Viet Nam as one of the world's most vulnerable countries to the impacts of climate change. It contains targets that are linked to the overall approach to sustainable development and proposes a low-carbon development approach. This includes provisions on "developing new and recycled energies" such as wind, solar, biofuels, and other technologies, so that they will constitute $5 \%$ of the country's total primary energy (not power outputs alone) by 2020 and $11 \%$ by 2050 . The strategy also promotes energy efficiency measures and advocates steps to reduce the energy intensity of the economy.

The National Action Plan to respond to climate change in 2012-2020 was approved on October 2012. This plan sets a portfolio of 65 programs, projects, and other activities as a means to implement the climate change strategy for the period up to 2020 . This includes assessment, planning, and activities intended to increase awareness in the priority sectors and the community of the need to respond and adapt to climate change. A number of thematic and/or location-specific studies and adaptation strategies have resulted from activities under the NTP and the National Action Plan. These have contributed to a deepening of understanding of both mitigation and adaptation activities appropriate for Viet Nam.

These earlier studies and strategies contributed to the 2015 Intended Nationally Determined Contributions (INDCs) presented at the UNFCCC Paris Conference of Parties (COP). The INDC sets out a GHG reduction pathway for the period 2021-2030 that will reduce GHG emissions by $8 \%$ by 2030 , compared to the business-as-usual scenario based on national contributions. This target can go up significantly to $25 \%$ with international support. It also identifies a series of adaptation measures that build on and extend existing initiatives. The INDCs list 254 existing Clean Development Mechanism projects, 87.6\% of which are in 
the energy sector. The energy sector, and in particular power generation, is identified as a key sector (along with agriculture, in relation to methane emissions) for future mitigation activities. The INDCs commit a 20\% decrease in the emission intensity per unit of GDP from 2010 levels. With international contributions, this can go up to $30 \%$. There are measures intended to improve energy efficiency, reduce energy consumption, and promote the development of renewable energy power generation.

Another policy area that is of growing relevance to power sector planning is decentralization, or the transfer of planning responsibilities and implementation budgets from central ministries to the provinces. For power generation, this means all power generation investments below $30 \mathrm{MW}$ will be planned and implemented at the provincial level. To date, this accounts for a very small percentage of the overall capacity expansion, mostly micro-hydropower plants. The national PDP contains only an overall figure for the future generating capacity from these investments but does not give any more information. The future will be very different, with the role of renewable energy in the revised PDP VII growing at a rapid rate. Most of this increased capacity will be in smaller facilities that must be planned and implemented at the provincial level. Decentralization policies and the need to build the capacity of the provinces to plan renewable energy effectively are key issues for the future development of the sector.

Decentralization was introduced as a central plank of national policy following the introduction of Doi Moi reforms in 1986. There has since been a progressive move to a greater role for provinces, through the Provincial People's Committees (PPCs). Decentralization was intended to improve the reliability and effectiveness of public service delivery, enhance accountability and governance at the provincial level, increase equity between levels of government, and promote stability. A key aspect of the process has been budgetary reform, with provinces now receiving funds for all but national-level investments directly from the Ministry of Finance rather than through line ministries. The legal basis for decentralization was consolidated in 2015 with the passing of two laws: the Law on the Organization of Local Government and the Law on the Organization of National Government. The 2016 Budget Law reinforced the financial provisions for decentralization. Taken together, these recent laws give provinces a clear mandate to plan, finance (including seeking private sector funding), and implement activities identified in provincial, sector, and overall development plans.

This is the structure through which most future investments in renewable energy will be planned and implemented. This means a concerted effort is necessary to ensure that provinces, especially those with a huge renewable energy resource potential, have the means and interest to plan for the expansion of investments in renewables. PPCs and other provincial stakeholders must be equipped so that the development of renewable energy can translate to local opportunities and reflect national priorities. Given the planned level of expansion of renewable energy in the revised PDP (RPDP) VII, building these capacities should be seen as an urgent priority.

The final and most recent legislation that needs to be considered is the 2017 Law on Planning (2017/QH14), passed by the National Assembly on 24 November 2017. This law consolidates the trend to move away from traditional sector-based master plan approaches with emphasis on greater coordination between national, regional, and provincial planning systems, and the requirement for greater coherence between sector plans and overall national development plans and approaches. Article 18 specifies that the agency responsible for preparing 
the plan will include an SEA in the plan preparation process, according to regulations on environmental protection. This provision consolidates SEA provisions beyond the LEP and into the core planning legislation of the country. Article 22 specifies the contents of national master plans such as PDPs, a provision that must be carefully considered when defining the scope and contents of future PDPs. It should also be noted that the law lists national sector plans, including an energy master plan and an electricity development plan. The nature of the new Law on Planning means the implications for future strategic planning in the power sector have yet to be established. What is clear is that the process through which these plans are prepared will need to be assessed to ensure conformity with the law's provisions.

\subsubsection{Energy Sector Policies and Strategies}

The 2004 Law on Electricity and the 2012 Law Amending and Supplementing a Number of Articles of the Electricity Law (Law No. 24/2012, approved on 20 November 2012), set the regulatory framework for planning and operating power generation, and supporting infrastructure and activities. Together they define the system for setting prices; lay down priorities for the development of the power generation system; and establish institutional responsibilities for the planning, expansion, and operation of the power generation and distribution system. These laws define the scope and responsibilities in the preparation of PDPs. The MOIT is responsible for the national plan while the people's committees are responsible for implementation plans at decentralized levels. The 2012 law changed the coverage period for PDPs to 10 years, with a revision after 5 years, depending on social and environmental issues, and an orientation for another 10 years. The 2012 law also sets a priority to increase and provide incentives for the use of renewable energy and other sources of new energies to expand the power generation system.

The 2007 National Energy Development Strategy up to 2020 and Vision 2050 state that the development of energy sources should contribute to socioeconomic development and be based on a balanced range of supply options, taking into account environmental sustainability as a key issue. This strategy set a framework that has been elaborated by more specific laws and policies in the decade since it was prepared.

The National Assembly passed Law No. 50/2010/QH12 on the Economical and Efficient Use of Energy on 17 June 2010. This law recognizes the need to improve efficiency and sustainability in power generation, and defines the "rights, obligations, and responsibilities of organizations, households and individuals in the economical and efficient use of energy." It requires power sector plans to maximize energy efficiency opportunities and link these to the national sustainable development and green growth approaches. This includes the application of advanced technologies to improve efficiency, reduce transmission losses, and stimulate the use and recycling of waste energy from thermal power generation plants.

Other measures adopted to stimulate the development of nontraditional forms of power generation were: (i) Decision No. 37/2010/QD-TTg on support mechanisms for the development of wind power projects, approved on 29 June 2010; (ii) Decision No. 24/2014/ QD-TTg on support mechanisms for the development of biomass power projects, approved on 24 March 2014; (iii) Decision No. 31/2014/QD-TTg on support mechanisms for the development of power generation projects using solid waste approved on 5 May 2014; and (iv) the government-issued Decision No. 11/2017/QD-TTg on encouragement mechanisms 
for the development of solar power, dated 11 April 2017. These are seen as representing limited but interesting opportunities for developing novel power generation sources that reflect the national situation with regard to solar, wind, biomass materials, agricultural residues, and solid waste from expanding urban areas.

The provisions of Decision No. 34/2010/QD-TTg, promulgating the regulation on irrigation and hydropower project-related compensation, support, and resettlement, approved on 8 April 2010, are important social protection measures relating to hydropower. This decision addressed issues identified in the SEA on hydropower in PDP VI and elsewhere on the limitations of the former compensation and resettlement system, bringing Viet Nam into line with international good practice in this area.

The Land Law dated 29 November 2013 has replaced the old Land Law 2003. This new law has significant innovations on (i) intensifying management and operation of land relations toward a market mechanism, progressing to eliminate subsidization in land management and utilization of land by the state without a land use fee; (ii) outlining a mechanism of state management and regulations on the establishment of a Land Development Fund; (iii) strengthening transparency in land management and utilization; and (iv) ensuring land use rights for disadvantaged social groups such as women, low-income groups, and ethnic minorities. The government's Decree No. 47/2014/ND-CP, dated 15 May 2014, promulgated important social protection measures related to compensation and support for resettlement during the process of occupation of land by the state. Measures related to hydropower development have been stipulated in Decision No. 64/2014/QD-TTg, approved on 18 November 2014, setting policies on relocation and resettlement of people in areas under irrigation and hydropower projects development. This decision addressed issues identified in the current practical experience in Viet Nam concerning the compensation and resettlement system, with the objective of aligning these activities with international good practice in this area.

A recent key policy was set out in Decision No. 2068/QĐ-TTg, approved on 25 November 2015, which outlines Viet Nam's Renewable Energy Strategy up to 2030 with an outlook to 2050. This strategy refers to both the expansion of renewable energy use and the development of a renewable energy industry, including incentives and support linked to market mechanisms. The decision includes targets for the development of renewable energy, which is a key component in the overall national green growth strategy, in national energy security and in the national response to climate change. The specific targets are:

(i) To increase the total production and use of renewable energy from 25 million ton of oil equivalent (TOE) in 2015 to 37 million TOE in 2020, 62 million TOE in 2030, and 138 million TOE in 2050. It should be noted that almost all the renewable energy production in 2015 came from large-scale hydropower but the potential for the expansion of hydropower is limited, which means the bulk of future expansion will come from other sources of renewable energy.

(ii) To increase the total electricity production from renewable energy sources from approximately 58 billion kilowatt-hour (kWh) in 2015 to 101 billion kWh in 2020, 186 billion $\mathrm{kWh}$ in 2030, and 452 billion $\mathrm{kWh}$ in 2050. The share of renewable energy-based electricity in the total national production will rise from 35\% in 2015 to $38 \%$ in $2020,32 \%$ in 2030 , and $43 \%$ in 2050. 
(iii) To reduce GHG emissions in energy activities as compared with the business-asusual scenario, by approximately 5\% in 2020, 25\% in 2030, and 45\% in 2050 .

(iv) To contribute to reduced fuel imports for energy purposes. This means reducing by approximately 40 million tons the country's coal imports and by 3.7 million tons its imported oil products by 2030 . By 2050, a reduction of 150 million tons of coal and 10.5 million tons of oil products is expected.

There are specific targets for different forms of renewable energy, including solar power, biomass technologies and biofuels, and wind energy. The mechanisms to achieve these targets are listed in the decision, including the formulation of a renewable energy market, policies on tariffs and guaranteed investments, institutional and capacity-development activities, establishment of national standards and norms, and financial support. International cooperation on the development of renewable energy is seen as essential for the success of the strategy.

\subsection{Conclusions}

It is clear from the above review of a wide range of policy and legislative initiatives over the last decade that Viet Nam has undertaken a detailed and sustained reform to its overall approach to national development, and the structure and focus of the power generation sector. These initiatives set the context within which the development of power sector planning must be done. The emphases on social and environmental responsibility, energy efficiency, and the expansion of the role of non-conventional renewable energy, on the mitigation of and adaptation to the impacts of climate change, on sustainability and green growth, and on greater private sector participation in the sector all mirror bigger changes in the country. The process through which power sector planning moves from a traditional least-cost PDP approach to the integration of an SEA in plan preparation is consequently not just a legal requirement given legislation on SEAs, it is also essential for the sector to be in line with the overall development aspirations and approaches of the country as a whole. Changes that have taken place over the last two PDPs (PDP VI and PDP VII) reflect an evolutionary approach to moving in this direction, but it is clear that further sustained action is needed if the full process of change and reform taking place at the national level is to be reflected in power sector planning. These issues are discussed in detail later in this report. 


\section{Evolution of Strategic Environmental Assessments in Power Development}

\subsection{Strategic Environmental Assessment of the Hydropower Master Plan in Power Development Plan VI}

The first Strategic Environmental Assessment (SEA) linked to the Power Development Plan (PDP) process to be undertaken in Viet Nam was the SEA of the Hydropower Master Plan in the context of PDP VI. This exercise was supported by ADB's Greater Mekong Subregion (GMS) Environmental Operations Center and undertaken, with the assistance of international consultants, by the Ministry of Industry and Trade (MOIT) and the Institute of Energy over a two-year period, 2007-2008. It was a pilot exercise done soon after the introduction of SEA as a legal requirement and was designed to build capacities for the integration of SEA into the strategic planning of hydropower in the country, including the preparation of PDP VII. The execution of the SEA followed six phases: (i) scoping; (ii) baseline; (iii) scenarios and alternatives; (iv) risk and impact assessment; ( $v$ ) weighting and trade-offs analysis; and (vi) reporting, including recommendations.

The SEA considered the potential impacts of the 21 large-scale hydropower schemes that were included in PDP VI. The Hydropower Master Plan suggested that these were the remaining technically and economically feasible large-scale hydropower schemes in Viet Nam and, in consequence, the SEA constituted an assessment of the remaining potential capacity in the sector. A key feature of the SEA was the use of scenarios, which provided an analytical tool that could compare the implications of different mixes of power generation sources for social and environmental sustainability. Five scenarios were considered, with a base case consisting of the existing schemes included in PDP VI, then four further scenarios that progressively reduced the number of hydropower schemes and replaced them with the least-cost alternatives (generally thermal power) identified through the PDP process. The impacts of the alternative generating sources were considered in each scenario, providing a meaningful analysis of the impacts of different options to meet the defined needs for generation capacity in PDP VI.

The scenario approach allowed stakeholders to assess the full implications of decisions on the level of hydropower that should be developed. The study demonstrated the potential effectiveness of SEA as part of a strategic planning process, such as PDP preparation, at a time when SEA was new to power sector planners in Viet Nam, many of whom had concerns that the new legislation on SEA would lead to considerable costs and time delays in the preparation of the PDP. This sentiment is one that has been expressed in other GMS countries (and beyond) and is an issue that needs to be directly addressed in the initial 
stages of the introduction of an SEA in the PDP process. The study demonstrated that an SEA should be decision-oriented, balanced, and evidence-based-characteristics that were well received in the sector, and the use of scenarios was in line with normal practice in the execution of the PDP.

The study demonstrated the potential of SEA as a key part of the strategic planning framework for the hydropower sector, providing for the first time in Viet Nam a process where the assessment of the full range of potential risks - for people and the environmentassociated with hydropower, both within and beyond the immediate vicinity of hydropower construction. It also integrated the identification and assessment of the most effective mitigation and compensation actions into the preparation of PDPs, including actions to reduce risks and compensate for negative impacts where they do occur.

A key innovation in the SEA was the development of a framework for the internalization of the costs of social and environmental impacts and mitigation measures in the assessment of the economic feasibility of hydropower schemes. This was done by comparing different risks and impacts that have distinctive characteristics, e.g., potential impacts on the culture and livelihoods of local communities versus risks to biodiversity resources and impacts on greenhouse gas (GHG) emissions.

The effectiveness of the SEA as a mechanism for strategic planning in the hydropower sector in Viet Nam demonstrated that the SEA approach is transferable not just to other sectors in the country but to hydropower planning and analysis in countries in and beyond the Mekong region. As such, as a pilot, this SEA was extremely successful: it showed that the approach works in a challenging context and can be applied elsewhere.

The assessment of risks and impacts in the SEA was done in three scales: (i) for the reservoir area, (ii) for a zone of influence surrounding each dam site, and (iii) for the wider area beyond this zone. The SEA showed that there is a wide range of potential social and environmental impacts, both positive and negative, from hydropower development. The degree of certainty that these impacts will occur within ranges from extremely high for the reservoir area, to low for the zones of influence and beyond. This means that impacts with the highest chance of occurring are best understood as risk factors and risks that can be reduced or removed by effective anticipatory mitigation measures.

The clearest positive impacts are for agricultural production, both within the zone of influence and further afield, and water resources management. Increased agriculture income could catalyze wider development benefits in remote locations. Similarly, improvements to dry season water availability and reduced flood risks will generate more development benefits.

The impacts on displaced people were assessed to be substantial, with a risk of creating deep and sustained impoverishment. The package of mitigation measures outlined in the SEA was seen as an essential part of the planning and cost of hydropower, if these risks are to be avoided and the sector is to develop in a socially responsible and sustainable manner.

Wider social impacts are less certain and more differentiated in their effects. These impacts relate to increased access to natural resources and the effects of opening up remote areas to external influences. The concentration of these impacts will be on the locality that will host the resettlement and on the areas surrounding the construction site for the dam. 
The risk of impacts on natural resources is significant. Potential losses of forest resources could be high. Aquatic resources will also be affected where river lengths are impacted by dam construction and changes to flow regimes.

The risk of biodiversity impacts could be severe in some cases. In particular, the risk of ecosystems fragmentation is significant where a high proportion of sensitive biodiversity areas are located close to the dam site. Many of Viet Nam's biodiversity assets are of global significance, and their loss would have consequences far beyond the immediate site.

The SEA demonstrated that the risks and impacts of hydropower development need to be assessed against the risks and impacts of alternative developments, such as the social and environmental impacts of the increase in thermal power generation based on natural gas or coal. The alternatives have their own risks and impacts. Any SEA of hydropower will not be complete unless an assessment of the alternatives to hydropower is included as an integral part of the analysis.

Overall, the analysis shows that: (i) the risks of social and environmental impacts from hydropower development are significant; (ii) these risks can, in most cases, be measured; and (iii) they can, to a significant degree, be mitigated if effective actions are taken. There are some schemes that are particularly problematic and will require concerted efforts to mitigate negative impacts, while some types of impact, such as those on aquatic environment, are harder to mitigate than others. Mitigation is, nevertheless, possible in most cases. Such actions entail costs - but not at a level where they compromise the financial viability of any of the hydropower schemes-and are good investments in terms of their overall economic returns to Viet Nam's sustainable development.

The approach to mitigating the impacts of hydropower development outlined in the SEA sought to maximize potentials, reduce risks, and compensate for negative impacts as an integral part of the investment planning included in the plan. The planning and construction of major infrastructure investments, such as dams and associated facilities, changes irrevocably, for better or worse, the localities in which they are built. This change should be seen as an opportunity to catalyze the development and transformation of what are often remote localities with high incidences of poverty, poor access to services, and limited opportunity to participate in the growth and change that characterizes contemporary Viet Nam. The SEA argued that developing hydropower is not just about generating electricity; it is about generating change, and this change can be steered in the direction of reducing poverty, sustaining the resource base, and fueling development, in addition to the primary purpose of meeting the country's electricity needs.

One of the mitigation methods recommended in the SEA report is the development of strong links to the Payment for Forest Environmental Services (PFES) program of the Government of Viet Nam, which is being progressively rolled out as the implementation of PFES is implemented nationwide following a successful pilot program in Quang Nam Province. ${ }^{10}$ The implementation of PFES, which is based on Decree 99/2010/ND-CP, and subsequent measures to detail its implementation mechanisms, is an example of effective links between

10 ADB. 2014. Scaling Up Payment for Forest Environmental Services in Viet Nam: Lessons and Insights from Quang Nam. Manila. 
the power sector and wider development policies. The program provides a mechanism where payments from hydropower schemes are directly channelled to upland communities who, in turn, take responsibility for forest protection in the watershed of dams, thereby ensuring greater sustainability of the hydropower scheme and of the local environment.

The SEA study has shown that hydropower development will affect communities and the environment in areas adjacent to where dams and reservoirs are constructed. It also showed that the potential environmental and social impacts of different energy sourcesespecially hydropower compared to thermal power generation-also vary. The development of strategic planning in the power sector, including sustainable hydropower development, needs to integrate the analysis of these factors in the sector's decision-making process. In the case of hydropower in PDP VI, analysis showed that the inclusion of wide-ranging mitigation measures for both social and environmental impacts will not significantly affect the economic feasibility of the hydropower schemes in the plan. In essence, developing hydropower in a sustainable manner that meets the highest international standards is both achievable and affordable.

Lessons from the pilot SEA revealed the changes needed in the PDP planning to ensure that social and environmental impacts were fully integrated into the process. A detailed model of how to achieve this was advanced in the final chapter of the study. This model was used to inform the development of the SEA in PDP VII, which was based on the experiences and capacities developed in the execution of the pilot hydropower SEA linked to PDP VI.

The summary points and lessons from the pilot SEA of hydropower in Viet Nam were included in the SEA report, as follows:

(i) SEA provides a powerful tool for the analysis of the social and environmental impacts of hydropower development and can be fully integrated into the overall strategic planning process for the power sector, particularly in the preparation of PDP VII.

(ii) The level of hydropower development envisaged in PDP VI can be justified when compared to the feasible alternative sources of power generation, which have higher economic, social, and environmental costs.

(iii) The present approaches to address social and environmental issues in hydropower development are inadequate. More effective mitigation and compensation measures must be introduced if hydropower development in the country is to follow a more sustainable path.

(iv) Most of these necessary social and environmental mitigation measures can be costed out, and these costs can be internalized into the overall economic analysis of hydropower schemes without compromising their financial or economic viability.

(v) There are opportunities in areas such as water management, agricultural development, service provision, and poverty reduction for positive impacts from hydropower development, but these positive benefits are not yet fully recognized or realized.

(vi) Many mitigation measures need to be introduced proactively, before development starts, to reduce the risks of negative impacts. The measures will not be effective if they are introduced too late. 
(vii) A number of mitigation measures can be linked to existing government programs in other sectors, such as the Program 135, the Community Forestry Program, and the Protected Areas Development and River Basin Planning. Tapping into such links will reduce the costs and increase the effectiveness of mitigation measures.

(viii) Capacity development is necessary in many parts of the system for planning and implementing hydropower development if the potential of the SEA as a strategic planning tool is to be realized.

(ix) Knowledge and data gaps exist and need to be addressed for a more effective integration of social and environmental issues into power sector planning.

(x) Benefit sharing mechanisms have been piloted and proven to be effective. These mechanisms can more effectively link hydropower to the wider development processes in the vicinity where schemes are constructed.

\subsection{Strategic Environmental Assessment of Power Development Plan VII}

\subsubsection{Overall Structure of Power Development Plan VII}

The original PDP VII was prepared in 2011 to guide the development of the power sector for the period 2011-2030. It analyzed likely future electricity demand scenarios by sector, taking into account potential economic and social development trends. It also assessed the most effective, least-cost power generation options for meeting such future demand patterns. The preparation of the plan's SEA was done simultaneously with the plan preparation. While there was close coordination at the different stages of analysis in the PDP and the SEA preparation, there were still limitations in the extent to which the SEA was fully integrated into the PDP process. The preparation of the SEA for PDP VII represents a significant step, but it was not the finished article.

The SEA in PDP VII analyzed the potential social and environmental impacts of the power generation options and the expansion of the transmission line system contained in the PDP VII base case. The central goal of PDP VII — to meet future demand through the most effective and responsible strategy for the expansion of generation capacity-required tradeoffs between the costs and benefits associated with different types of power generation. These contrasting sets of costs and benefits were examined in the SEA, and clear conclusions and recommendations were made to determine the most effective strategy for the future development of the power sector in Viet Nam.

The preparation of forecasts of future power demand was based on the analysis of current power consumption data for each sector, combined with assumptions on the speed and structure of economic development during the plan period, and savings from energy efficiency improvements. Three growth scenarios were used to estimate future patterns of demand: (i) a high-growth scenario in which economic development remains above $9 \%$ for the period up to 2030 , (ii) a base scenario in which growth is around $8 \%$ for the period, and (iii) a low-growth scenario where economic growth is between $7 \%$ and $7.66 \%$ for the plan period. A least-cost modelling exercise, based initially on financial and technical 
criteria, was then made to identify the most appropriate generation options to meet this forecast demand. The results were a balance between different power generation options, with the expansion of thermal power, especially coal, dominating the scenarios. The SEA considered the social and environmental impacts of the different generation options, under the abovementioned base case scenario. The results are summarized below:

Thermal power is the largest single element of the proposed expansion of power generation in the different scenarios of PDP VII, so it is no surprise that it is also the source of the most significant potential social and environmental impacts in each scenario. The impacts of the atmospheric pollution resulting from the combustion of fossil fuels used, particularly coal, are by far the greatest risks associated with thermal power. Under the plans in PDP $\mathrm{VII}$, carbon dioxide $\left(\mathrm{CO}_{2}\right)$ and particulate matter releases from coal-fired generation would increase more than tenfold during the PDP VII period up to 2030; the release of sulfur dioxide $\left(\mathrm{SO}_{2}\right)$ will increase by a factor of seven and nitrogen oxides $\left(\mathrm{NO}_{x}\right)$ will increase by some four times. The impacts of these atmospheric pollutants would be severe and widespread. These impacts have been valued (Table 2), and it is estimated that they would cost Viet Nam nearly $\$ 9$ billion per year by 2030 unless actions are taken to reduce the levels of atmospheric pollutant releases from, in particular, coal-fired power generation.

\section{Table 2: Total Environmental Costs for Each Pollutant in the Original Power Development Plan VII, 2011 (\$ million)}

\begin{tabular}{|lrrrrr|} 
Year & 2011 & 2015 & 2020 & 2025 & \multicolumn{1}{c}{2030} \\
\hline $\begin{array}{l}\text { Particulate } \\
\text { matter }\end{array}$ & 98.86 & 134.95 & 289.57 & 439.40 & 710.24 \\
$\mathrm{SO}_{2}$ & 93.77 & 148.09 & 311.85 & 448.18 & 728.74 \\
$\mathrm{NO}_{x}$ & 234.15 & 274.48 & 386.09 & 494.30 & 638.86 \\
$\mathrm{CO}_{2}$ & $1,215.50$ & $2,190.50$ & $4,118.70$ & $6,075.90$ & $9,071.90$ \\
\hline
\end{tabular}

$\mathrm{CO}_{2}=$ carbon dioxide, $\mathrm{NO}_{x}=$ nitrogen oxides, $\mathrm{SO}_{2}=$ sulfur dioxide.

Source: Government of Viet Nam, Ministry of Industry and Trade. 2011. Strategic Environmental Assessment of the National Plan for Power Development for the Period 2011-2020 with Perspective to 2030 (PDP VII). Ha Noi.

The impact of the atmospheric pollutants from thermal power is significant where the planned sites of the new thermal power stations are close to major urban areas, where existing ambient air quality is often already poor and where higher population densities are found. This was especially true in the case of the planned clusters of thermal stations close to Ho Chi Minh City and, to a lesser extent, in the northern region southeast of Ha Noi (Figure). If constructed, these planned clusters would lead to a cumulative effect where the impacts of one individual station may not be so severe, but where the effects of several stations located close to each other in the proximity of large populations is a serious issue that should be addressed in the PDP VII plans.

Hydropower is the second largest source of the expansion of power generation in PDP VII. The construction of hydropower schemes has the potential to produce a range of negative social and environmental impacts, including loss of land and ecosystem disruption, 


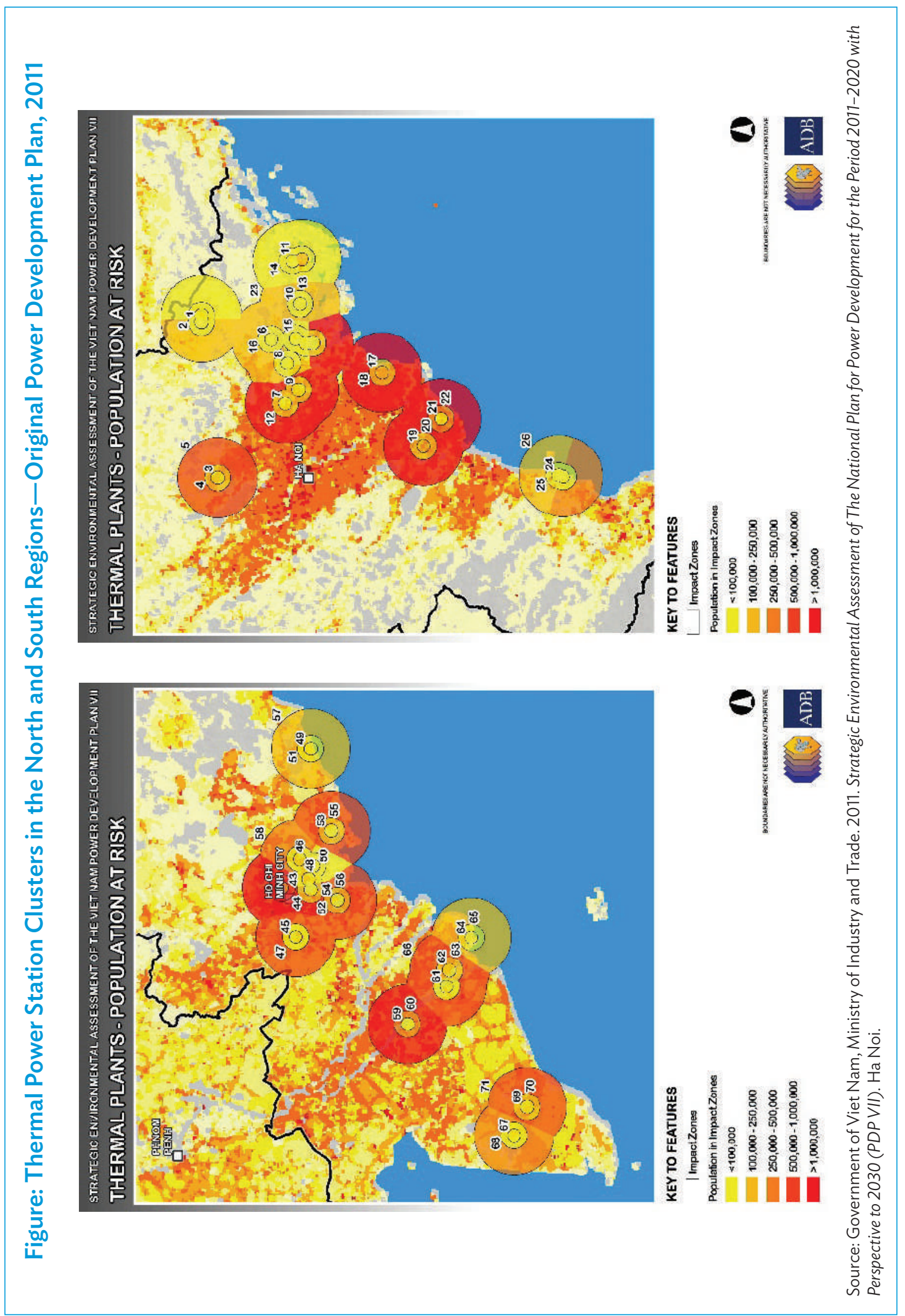


displacement of people and impacts on communities not physically displaced, and disruption to hydrological systems and ecosystems that depend on them. Many of these happen during the construction of the dam and flooding of the reservoir. There are also wider effects on people and the environment that are a mix of positive and negative impacts. These include improvements to water flow in the dry season, which can benefit the river basins but also damage the ecosystems of rivers in the immediate vicinity of hydropower schemes. The impacts of hydropower development are complex and widespread. In some cases, they may be minimized through sustainable approaches to hydropower in the planning and development of the schemes.

The reservoir area includes different types of land lost, such as farmland, forests and habitation. Each type has subcategories that reflect the impacts on displaced people. The total area that will be submerged in the 21 schemes in the plan is 25,133 hectares (ha), of which 4,227 ha are natural forests; 1,367 ha are plantations; 5,961 ha are agricultural land; 737 ha are residential land; and 12,810 ha are grasslands, bare land and other non-productive land. It is estimated that the value of the crops from the lost farmland, would be around $\$ 2.9$ million per year, while the total resource value of the forest lost, including environmental service functions, is estimated at $\$ 72.4$ million.

If all 21 large hydropower generation schemes were constructed, 61,571 people would be displaced, although the number varies from scheme to scheme. Seven of the schemes would require little or no resettlement, and three would result in the displacement of 650 people or even fewer. However, the Bac Me scheme would displace 10,700 people and the Ban Chat scheme would displace 14,800 people. The four schemes that would affect more than 7,000 people (Ban Chat, Bac Me, Huoi Quang and Lai Chau) would result in the displacement of over 41,000 people, or two-thirds of the total affected population. The construction of these schemes would require special attention on resettlement. Over $90 \%$ of the displaced people would be ethnic minorities, among whom poverty incidence is more than double the national average. These people are highly dependent on access to natural resources, especially forests, for their livelihoods, and a close connection to where they live is an integral part of their cultural identity.

Nuclear power would be a new development option and was included in PDP VII (although at the time of writing, the Government of Viet Nam has shelved all proposed nuclear power plans). Nuclear power is characterized by risks that have a low probability of occurring but have huge impacts if they do occur, reflecting the extreme hazards associated with the use and management of radiological materials. Should the country decide to develop nuclear power in the future, significant investments in capabilities and management systems to handle radiological materials must be made before nuclear power development starts. There are also potential impacts that need to be assessed, including those stemming from the very high levels of cooling water that nuclear power stations require. The site selection of the power station is critically important here; in particular, locations that are close to sensitive or high-value ecological areas must be avoided. The risk of natural disasters affecting nuclear power stations must also be considered in selecting the nuclear plant site. The possible impacts of cooling water on riverine and marine ecosystems also requires careful assessment.

The expansion of the transmission lines system was assessed in terms of social and environmental impacts, with the analysis raising concerns over the loss of valuable forests and the fragmentation of sensitive ecosystems. The assessment in the SEA showed that 
the transmission line expansion proposed in the original PDP VII would result in the loss of 14,103 ha of forests, including 7,739 ha of rich forests in the highest quality category. The valuation of these forest resources in ecosystem service terms came to $\$ 218$ million. In addition, the original routes for the line expansion would pass through 59 protected areas and 39 key biodiversity areas, with 3,387 ha to be cleared in protected areas and 2,297 ha to be cleared in key biodiversity areas. This would result in the fragmentation of vulnerable and high-value ecosystems, compromising the ecological viability of certain protected areas. The SEA recommended measures to consolidate and re-route transmission lines to reduce these potentially adverse impacts.

The assessment of impacts from the base case scenario led to the further development of the SEA as a means to identify the potential of actions to reduce the impact of air pollution from thermal power in particular, as that was assessed to be the dominant area of concern from the power generation options identified in the base case. After discussions and consultations, it was decided that two additional scenarios should be developed as an extension of the PDP modelling process: a scenario that incorporated greater energy efficiency savings and a scenario with an expanded level of renewable energy production.

\subsubsection{Improved Energy Efficiency}

The demand-side management study by Vietnam Electricity (EVN) shows that a savings potential of around $36 \%$ could be achieved in the residential sector, more than $20 \%$ in the industrial sector, and over $12 \%$ in the commercial sector if the country can improve its energy efficiency." The World Bank's Commercial Energy Efficiency Program, which involves pilot projects in commercial and industrial sectors, projects savings to be 15\%-30\%. . $^{12}$ Although challenging, it is possible to significantly improve energy efficiency in Viet Nam. The EVN study considered measures to achieve this.

A study supported by the Government of Denmark established that compliance with the existing minimum efficiency standards in the building sector could lead to savings of $30 \%$ or more, compared with the current building practice..$^{13}$

The implementation of these energy efficiency measures and related targets can bring down the country's elasticity of electricity demand in relation to GDP growth (ratio of growth rate of electricity demand and growth rate of GDP) from a high of 1.90 in 2010 to 0.85 in 2030 , which is consistent with such elasticity rates of many energy-efficient developing and developed countries.

A scenario was analyzed in which the plans in the PDP VII base case were adjusted to increase energy efficiency according to the strategy set out in the Vietnam Energy Efficiency Program for the period 2010-2015. The Vietnam Energy Efficiency Program, an MOIT program developed in 2009, pegged electricity savings at 5\%-8\%, gradually increasing this to $20 \%$ of the total electricity demand for the period 2015-2030. This scenario includes 46 coal power

11 International Institute for Energy Conservation. 2007. Vietnam Demand Side Management and Energy Efficiency Program Assessment Report. Bangkok.

12 World Bank. 2010. Vietnam Expanding Opportunities for Energy Efficiency. Washington, DC.

13 Danish Energy Agency. 2015. The Joint Danish-Vietnamese Cooperation on Energy Efficiency. Copenhagen. 
plants with a total capacity of 53,560 MW, as well as a balance of other thermal, hydropower, nuclear, and other generation sources. Under this scenario, electricity generation savings increase from 1,639 gigawatt-hour (GWh) in 2015 to more than 22,000 GWh by 2030. The reduction of electricity demand could lower dependency on coal-fired power generation, which means 16 coal-fired power plants identified in the baseline scenario will no longer be needed during the PDP period 2015-2030.

The results show the benefits of improving energy efficiency as part of plans to reduce the negative impacts of coal-fired power generation. The energy savings would translate to a reduction of 56 million tons of coal every year by 2030 . This in turn will reduce $\mathrm{CO}_{2}$ emissions by over 100 million tons a year, $\mathrm{SO}_{2}$ emissions by over 72 million tons, $\mathrm{NO}_{x}$ emissions by over 42 million tons, and particulate matter emissions by nearly 10 million tons a year (Table 3 ). These reduced emissions would scale down climate change and acidification impacts, and lessen the risks to human health from thermal power generation. The economic value of these reduced social and environmental impacts is calculated to be over $\$ 3.3$ billion a year by 2030 , a figure that would be much higher than any likely costs of the energy efficiency measures and investments implemented.

\section{Table 3: Reduction of Pollutant Emissions Compared to the Base Case through Energy Efficiency Measures Relative to Base Case in the Original Power Development Plan VII, 2011}

\begin{tabular}{|lrrrrr|} 
Year & 2011 & 2015 & 2020 & \multicolumn{1}{c}{2025} & \multicolumn{1}{c}{2030} \\
\hline $\begin{array}{l}\text { Particulate } \\
\text { matter }\end{array}$ & 312.91 & 995.04 & $3,552.45$ & $4,933.26$ & $9,873.90$ \\
$\mathrm{SO}_{2}{ }^{a}$ & $4,538.23$ & $5,837.31$ & $22,184.68$ & $32,609.93$ & $72,868.86$ \\
$\mathrm{NO}_{\times}{ }^{a}$ & $12,140.97$ & $113,65.97$ & $20,593.53$ & $29,154.38$ & $41,291.30$ \\
$\mathrm{CO}_{2}{ }^{\mathrm{b}}$ & $6,921.10$ & $115,08.16$ & $39,806.59$ & $49,275.07$ & $104,685.02$ \\
\hline
\end{tabular}

$\mathrm{CO}_{2}=$ carbon dioxide, $\mathrm{NO}_{\mathrm{X}}=$ nitrogen oxide, $\mathrm{SO}_{2}=$ sulfur dioxide .

a measured by tons

b measured by 1,000 tons

Source: Strategic Environmental Assessment report for Revised Power Development Plan VII 2012.

\subsubsection{Increased Renewable Energy in Power Generation}

The second major element of an approach to reduce coal-fired power generation is to generate electricity from other sources. Under the base case of PDP VII, the share of renewable energy increases from 3.6\% in 2015 to 5.8\% in 2025 but declines to $4.4 \%$ in 2030 due to the rapid growth of coal-fired power generation. In absolute terms, renewable energy's capacity increases from 1,679 MW in 2015 to 6,029 MW in 2030. These figures are much lower than the potential renewable energy development given resources such as wind, solar power, and mini-hydro.

The analysis in the renewable energy scenario included an increased proportion of renewable energy in the plan from $4.1 \%$ in the base case to $8 \%-10 \%$ based on the PDP VII expanded case, which would mean a capacity expansion of an additional 7,800 MW by 2030 when 
compared to the base case. The target is to attain almost $5 \%$ share in $2015,8 \%$ in 2020 , and close to $10 \%$ in 2030 . This would mean raising renewable energy capacity from 1,979 MW in 2015 to 13,829 MW in 2030, more than double the level found in the PDP VII base case scenario. Small hydropower systems would increase from $461 \mathrm{MW}$ in 2011 to 3,129 MW in 2030. Wind power generation would increase to $2,900 \mathrm{MW}$ by 2030 . For this renewable energy scenario, an additional 4,800 MW of small hydropower systems and 3,000 MW of wind power plants should be installed. This expansion would result in the reduced use of coal for power generation of 10.6 million tons and the reduction in atmospheric pollution shown in Table 4.

\section{Table 4: Reduction of Atmospheric Pollution from Expanded Renewable Energy Relative to Base Case in the Original Power Development Plan VII, 2011}

\begin{tabular}{lrrrrr} 
Year & \multicolumn{1}{c}{2011} & \multicolumn{1}{c}{2015} & \multicolumn{1}{c}{2020} & \multicolumn{1}{c}{2025} & \multicolumn{1}{c}{2030} \\
\hline $\begin{array}{l}\text { Particulate } \\
\text { matter }\end{array}$ & -7.03 & 35.23 & 223.81 & 849.02 & $1,941.73$ \\
$\mathrm{SO}_{2}{ }^{a}$ & 377.61 & 818.72 & 940.08 & $4,865.65$ & $13,575.04$ \\
$\mathrm{NO}_{x}{ }^{\mathrm{a}}$ & $12,356.55$ & $11,253.20$ & $10,166.70$ & $13,561.26$ & $14,575.81$ \\
$\mathrm{CO}_{2}{ }^{\mathrm{b}}$ & $7,440.86$ & $6,635.29$ & $7,056.78$ & $14,736.98$ & $26,264.91$ \\
\hline
\end{tabular}

$\mathrm{CO}_{2}=$ carbon dioxide, $\mathrm{NO}_{\mathrm{X}}=$ nitrogen oxide, $\mathrm{SO}_{2}=$ sulfur dioxide .

a measured by tons

b measured by 1,000 tons

Source: Strategic Environmental Assessment Report for Revised Power Development Plan VII, 2012.

These lower emissions from expanded renewable energy generation would cut environmental costs by over $\$ 1.7$ billion by 2030 when compared to the base scenario, and significantly lower human health impacts from the power generation sector. These permanent and sustained savings would outweigh any increase in the direct financial cost of generating renewable energy. It is likely that the economics of renewables, when compared to conventional power generation sources, will change in the coming decades with technological developments and economies of scale as the amounts of renewable energy used around the world continues to expand. This conclusion, made at the time of the original PDP VII SEA in 2012, has been reinforced by recent trends. In 2017, the levelized cost of generating some forms of renewable energy are lower than those of conventional power sources.

\subsubsection{Revision of Power Development Plan VII}

The results of the original PDP VII, including the chapter on the SEA, were presented to the Government of Viet Nam for consideration. Following consultations, the government sought a substantial revision of the PDP, which should include new scenarios and a modified set of power generation options. Although several factors were cited in this decision to revise PDP VII, two were particularly important: (i) the need to reduce the predicted growth of demand to reflect more realistic assumptions about the rate and structure of economic growth and patterns of demand for electricity; and (ii) the need to identify power generation options that 
would substantially reduce air pollution from coal-fired stations and thus, align the PDP with national policies on sustainable development, green growth, and climate change mitigation.

The second factor reflected the outcomes of the SEA based on scenarios of increased energy efficiency measures and renewable energy generation, as presented in the original PDP VII report. Doing the SEA while preparing the PDP VII demonstrates that it is possible to address the adverse impacts of the original proposals for power sector development that had been identified through more traditional, least-cost criteria. The process of revising the PDP VII allowed the full integration of the SEA into the PDP preparation, using SEA findings to identify the scenarios that were at the heart of the PDP revision. 


\section{Strategic Environmental Assessment of the Revised Power Development Plan VII}

\subsection{Structure of the Revised Power Development Plan VII}

The scope of revision of the original Power Development Plan (PDP) VII was considerable enough to constitute, in effect, a new PDP, even if based on the original plan. During the revision, the Strategic Environmental Assessment (SEA) findings were instrumental in defining the scenarios and their scope for analysis. The objectives set by the government for the revision of PDP VII included directions to reflect lower projections for future demand and significantly reduce the proportion of coal-fired generation capacity. This reduction in the use of coal was seen as crucial to reduce the negative impacts of air pollution and mitigate potential greenhouse gas (GHG) emissions. It brought the preparation of revised PDP VII closely in line with the national priorities for green growth and low-carbon development.

The revision process took some time and went through several iterations. The revised PDP (RPDP) VII was approved in March 2016 (Decision 428), 5 years after the original PDP VII was submitted. This long revision process was partly why the regulations concerning the timing and duration of PDPs were changed under the 2016 legislation, "Amending and Supplementing a Number of Articles of the Electricity Law" (Law No. 24/2012, approved on 20 November 2012). This law changed the coverage period of PDPs from 5 years to 10 years, with a substantial revision in the plan after the first 5 years. This put the approval of RPDP VII in line with the law.

The analysis in RPDP VII was based on three scenarios that reflected the outcomes of the SEA in the original PDP VII. The first scenario (PA1) was a base case that projected economic growth at 7\% per year throughout the plan period 2015-2030, and the growth of demand for power to be much lower than in the original PDP VII (Table 5). The figures in PA1 include assumptions of slower socioeconomic growth and significant energy savings due to a sustained national program on energy efficiency. These figures better reflect the national development priorities, e.g., a substantial increase in renewable energy and a major decrease in GHG emissions from the original PDP VII base case. The evidence used to create this first scenario largely came from the original SEA, which had a mix of generation sources that reflected the government's policy priorities and the economic cost of power generation alternatives.

The second scenario (PA2) used the same patterns of growth of demand as PA1, including energy efficiency savings, but increased the proportion of renewable energy (other than large hydropower) to $6.5 \%$ of the total generating capacity. Under PA2, the total generating capacity in $\mathbf{2 0 3 0}$ was higher than the base case to reflect the variable nature of some 
renewable energy sources and ensure the supply of electricity. The levels of renewable energy in this scenario were the highest feasible at the time of the analysis during the revision of PDP VII. However, developments in solar, wind, and other renewable energy technologies indicate that it is possible for renewable energy to have a bigger share in power generation. The lower costs and technical improvements of producing renewable energy should be anticipated and reflected in future PDPs.

The third scenario (PA3) was a high load scenario. It was prepared to test the implications of a situation where energy efficiency savings were not achieved, and levels of demand were higher than in the base case of RPDP VII. This scenario does not replicate the original PDP VII as it still aims to reduce coal generation and increase the use of renewables in a situation where generation capacity needs are higher than predicted. PA3 can be considered a sensitivity analysis and is seen to be the least likely of the three scenarios to transpire.

With the publication of the national Renewable Energy Development Strategy (Decision 2068/QD-TTg) in November 2015-while the scenarios were being analyzed-stakeholders wanted to explore renewable energy. This led to the creation of two more scenarios in which the role of renewable energy in the future generation mix was enhanced (Table 6). Both scenarios show a major expansion in renewable energy production and a decline in coalfired power generation.

\section{Table 5: Revised Power Development Plan VII Scenarios: First Iteration, 2016}

\begin{tabular}{lcccc}
$\begin{array}{l}\text { Energy- } \\
\text { Generating } \\
\text { Source }\end{array}$ & $\begin{array}{c}\text { Original PDP VII } \\
\text { (Base Case) }\end{array}$ & $\begin{array}{c}\text { RPDP VII } \\
\text { PA1 (Base Case) }\end{array}$ & $\begin{array}{c}\text { RPDP VII } \\
\text { PA2 (Renewable } \\
\text { Energy) }\end{array}$ & $\begin{array}{c}\text { RPDP VII } \\
\text { PA3 (High Load) }\end{array}$ \\
$\begin{array}{l}\text { Demand forecast } \\
\text { 2020 (GWh) }\end{array}$ & 251,763 & 227,724 & 227,724 & 269,339 \\
$\begin{array}{l}\text { Demand forecast } \\
\text { 2030 (GWh) }\end{array}$ & 548,800 & 456,436 & 456,436 & 582,177 \\
$\begin{array}{l}\text { Total generation } \\
\text { capacity 2030 } \\
\text { (MW) }\end{array}$ & 137,388 & 117,461 & 119,261 & 127,199 \\
$\begin{array}{l}\text { Coal (MW) } \\
\begin{array}{l}\text { Natural gas and oil } \\
\text { (MW) }\end{array}\end{array}$ & 17,465 & 21,088 & 21,088 & 23,218 \\
$\begin{array}{l}\text { Hydropower and } \\
\text { pumped storage } \\
\text { (MW) }\end{array}$ & 21,125 & 20,831 & 20,831 & 20,831 \\
$\begin{array}{l}\text { Other renewable } \\
\text { energy (including } \\
\text { small hydro) } \\
\text { (MW) }\end{array}$ & 4,829 & 11,849 & 14,849 & 11,849 \\
$\begin{array}{l}\text { Nuclear (MW) } \\
\text { Imported (MW) }\end{array}$ & 10,700 & 57,585 & 56,385 & \\
\hline
\end{tabular}

GWh = gigawatt hour, MW = megawatt, PA = Scenario No., PDP VII = Power Development Plan VII, RPDP VII = Revised Power Development Plan VII.

Source: Institute of Energy for Ministry of Industry and Trade. 2016. Report on Adjusted National Electricity Planning for 2011-2020, taking into consideration 2030. Ha Noi. 
Table 6: Enhanced Renewable Energy Scenarios for Revised Power Development Plan VII, Second Additional Iteration, 2016

(MW)

\begin{tabular}{lcc|} 
& $\begin{array}{c}\text { Feasible Renewable Energy } \\
\text { Development } \\
\text { (Scenario selected for the final } \\
\text { RPDP VII) }\end{array}$ & $\begin{array}{c}\text { Renewable Energy Development } \\
\text { (2015 Strategy) }\end{array}$ \\
\hline $\begin{array}{l}\text { Generation capacity } \\
2030\end{array}$ & 129,508 & 140,158 \\
Coal & 55,252 & 51,252 \\
Natural gas and oil & 19,078 & 18,328 \\
$\begin{array}{l}\text { Hydropower and } \\
\text { pumped storage }\end{array}$ & 21,871 & 21,871 \\
$\begin{array}{l}\text { Other renewable } \\
\text { energy (including } \\
\text { small hydro) }\end{array}$ & 27,199 & 42,599 \\
Nuclear & 4,600 & 4,600 \\
Imported & 1,508 & 1,508 \\
\hline
\end{tabular}

MW = megawatt, RPDP VII = Revised Power Development Plan VII.

Source: Institute of Energy for Ministry of Industry and Trade. 2016. Report on Adjusted National Electricity Planning for 2011-2020, taking into consideration 2030. Ha Noi.

The Feasible Renewable Energy Development Scenario was, after further analysis and discussion, selected for inclusion in the final version of the RPDP VII presented to the government and approved in Decision 428 in March 2016. Under this decision, it is anticipated that total electricity generation from renewable energy will be 14.6 terawatthour (TWh) in 2020 and 60 TWh in 2030. The preparation process for RPDP VII reflected a dynamic interaction between the SEA and the analysis of power generation options, which proved to be far more effective in assessing social and environmental impacts of power generation options.

This is most clearly reflected in the roles of coal and renewable energy in the final RPDP VII versus the original PDP VII. The anticipated level of coal-fired power generation in the year 2030 declined from 77,160 MW in the original plan (Table 5) to 55,252 in the revised plan (Table 6). Other renewable energy sources, including small and large hydro, and pumped storage, increased from 4,829 MW in the original plan to 27,199 MW in the revised plan. These changes mean that the final version of RPDP VII was far more in line with overall government policies and had effectively responded to the concerns raised over the original PDP VII proposals.

An important feature of the calculations used to define the generation options included in the scenarios is that the costs of social and environmental impacts, where they could be calculated, were included in the final iteration of the scenario analyses. This represents an important innovation as it is the first time that impact factors, traditionally treated as externalities, were internalized into the cost calculations for the different generation options in the plan. 


\subsection{Calculation of Externalities in the Revised Power Development Plan VII Scenarios}

A range of indicators were used to calculate the impacts of the different generation sources in the revised PDP scenarios. In most cases, these were indicators that had been identified in the original PDP VII SEA, but more persistent efforts were made to calculate them. The results of these calculations were integrated into the scenario analyses. The indicators covered the main potential impacts from thermal power, hydropower, nuclear power, renewable energy generation, and the extension of the transmission line system. Additional information on evaluation methods and sources of information related to the externalities indicators are presented in Appendix 1.

Coal-fired power generation is the largest source of new capacity in the revised PDP scenarios. Concerns over the impact of coal, along with other forms of thermal power, were central to the instruction to revise PDP VII. Sustained efforts were made to calculate the costs of the impacts of air pollution emissions from the planned coal-fired stations in the scenarios. This was done by analyzing the following indicators:

Thermal power indicators focused on three aspects of the impact of air pollution: (i) climate change, where total tonnage of GHG emissions and the economic valuation of the impact of these emissions were calculated; (ii) acidification, with total $\mathrm{SO}_{2}$ and $\mathrm{NO}_{x}$ emissions calculated and, where possible, information on the $\mathrm{pH}$ acidity values of water bodies likely to be impacted by flue gas emissions from power stations was assessed (but not valued); and (iii) health impacts through the assessment of total particulate matter emissions and the number of people exposed to health risks from air pollution. An attempt to calculate the economic costs of the impacts on human health was made but concerns were raised over the reliability of these estimates. The impact of thermal power on other factors was assessed, e.g., habitat loss and impacts on vulnerable ecosystems, number of displaced people, the effects of the discharge of cooling waters from power plants on riverine and marine ecosystems, and the volume of-and land required for-solid waste disposal.

Hydropower indicators covered a wide range of issues, with the analysis reflecting that undertaken during the preparation of the SEA of hydropower in PDP VI (all schemes included in PDP VI and PDP VII were considered in this RPDP VII analysis). This included the following indicators: (i) the total number of displaced people and the economic cost of providing a compensation package and resettlement support for them that meets international good practice on resettlement; (ii) the number of people whose livelihoods would be affected by the development of the hydropower schemes; (iii) the loss of forest cover, with both the total area lost or degraded and the corresponding economic value of the forest calculated in terms of ecosystem services; (iv) the total area and economic value of sensitive ecosystems affected by the hydropower schemes; and ( $v$ ) the hydrological impacts, including reduced downstream water availability, changes to dry season flows, and length of aquatic ecosystems affected in rivers below the dams.

Nuclear power risks and potential impacts were outlined but not quantified because the actual sites of the prospective nuclear power stations were not known. The need for radiological safety and a sustainable system for handling radiological materials were outlined 
along with risks associated with natural disasters and the potential impacts of discharging cooling waters.

Renewable energy impacts were also outlined but not quantified as details of the configuration and location of renewable energy generating capacity were not known. Issues associated with the land needed for renewable energy schemes were discussed along with potential visual and noise impacts.

Transmission lines impacts were calculated and valued where possible, including: (i) the area and economic value of forests that would be cleared for the extension of the transmission system; (ii) the fragmentation of sensitive ecosystems in protected areas and key biodiversity areas, based on geographic information system (GIS)-based analysis of the transmission line routes; and (iii) the number of people potentially affected by exposure to electromagnetic fields along transmission line routes.

Taken together, this set of indicators gives a detailed picture of the potential impacts of the various power generation options in the scenarios for RPDP VII. The quantification and valuation of certain indicators show that the economic analysis of these generation options could include social and environmental impacts that had traditionally been treated as externalities in the preparation of PDPs. (Footnote 6, definition of externalities).

\subsection{Analysis of Impacts}

The assessment of the social and environmental impact indicators discussed above was instrumental in deciding which generation options should be included in the revised PDP VII, which was approved in March 2016. The final decision reflected a balance between the investment costs and fuel costs over the plan period for each scenario, the social and environmental impacts, and the reliability of power supplies from each mix of generation sources.

The first two scenarios, PA1 and PA2, were most aligned with government policies and priorities, and consequently, compared in greater detail. PA3 was analyzed mainly to understand the implications of the failure to implement energy efficiency measures during the plan period. The cost of PA1 was $\$ 408.64$ billion: $54.4 \%$ or about $\$ 222.4$ billion was fixed cost and $44.1 \%$ or $\$ 180$ billion was fuel cost. The cost of PA2 was $\$ 409.66$ billion, higher by $\$ 1$ billion than PA1. The huge fixed cost largely accounts for the increase, which is around $\$ 2.5$ billion, but it was partly offset by a significant decrease in the fuel cost, which is around $\$ 1.5$ billion. That means the investment cost of renewable energy is higher, but the operating cost is lower.

The comparison of PA1 and PA2 showed a mere $0.25 \%$ difference in their total costs, which is within any margin of error over assumptions about fuel prices. This analysis reflected prevailing prices in 2016, during the preparation of the revised PDP VII.

These figures did not include values for social and environmental externalities, which were calculated during the preparation of the SEA for RPDP VII. The most important externalities were those associated with the use of fossil fuels, particularly coal, in thermal power 
generation. The differences in fuel demand between the scenarios was significant. The total demand for coal by the year 2030 in PA3 would be nearly 3 million tons per year higher than in PA1, and over 4 million tons per year higher than in PA2. Even where this is balanced against higher investment costs and lower power supply reliability, the adverse impacts of air pollution that would result from these differences in fuel consumption were such that PA3 was deemed a nonviable alternative. The levels of different pollutants released in the emissions from the different scenarios is shown below (Table 7).

\section{Table 7: Predicted Flue Gas Emissions from Thermal Power Generation in the Different Scenarios of Revised Power Development Plan VII}

(tons)

\begin{tabular}{lrrrr|} 
& 2015 & 2020 & \multicolumn{1}{c}{2025} & 2030 \\
\hline PA1 & & & & \\
Particulate & 4,956 & 13,198 & 36,179 & 46,848 \\
$\mathrm{SO}_{2}$ & 47,934 & 107,572 & 219,863 & 268,901 \\
$\mathrm{NO}_{x}$ & 65,875 & 117,315 & 261,813 & 362,072 \\
$\mathrm{PA2}$ & & & & \\
Particulate & 4,956 & 13,198 & 36,132 & 46,804 \\
$\mathrm{SO}_{2}$ & 47,934 & 107,572 & 219,603 & 268,533 \\
$\mathrm{NO}_{x}$ & 65,875 & 117,315 & 261,206 & 361,492 \\
$\mathrm{PA3}$ & & & & \\
$\mathrm{Particulate}$ & 4,919 & 13,552 & 36,661 & 47,597 \\
$\mathrm{SO}_{2}$ & 47,578 & 110,047 & 224,268 & 274,683 \\
$\mathrm{NO}_{x}$ & 65,372 & 119,506 & 269,299 & 371,629 \\
\hline
\end{tabular}

$\mathrm{NO}_{x}=$ nitrogen oxide, $\mathrm{PA}=$ Scenario No., $\mathrm{SO}_{2}=$ sulfur dioxide.

Source: Institute of Energy for Ministry of Industry and Trade. 2016. Report on Adjusted National Electricity Planning for 2011-2020, taking into consideration 2030. Ha Noi.

Table 7 shows that under any scenario, the quantities of pollutants released will increase substantially - by almost 10 times for particulate matter, and 5 to 6 times for both $\mathrm{SO}_{2}$ and $\mathrm{NO}_{x}$. These figures are already an improvement over the quantities of pollutants that would have been released if the original PDP VII proposals, which involved greater reliance on coal plants, had been followed. The human and environmental health risks associated with these pollutants, however, will continue to rise dramatically under any of the scenarios in RPDP VII.

The level of air pollution is not the only issue to consider in the assessment of potential negative impacts. The location of the emission releases and its proximity to population centers, the concentrations of other sources of pollution such as industrial zones, the existing ambient air quality, and the siting of power stations in relation to prevailing wind directions are also important considerations. The SEA of the original PDP VII had raised concerns about the proposed sites of some thermal power stations in the northern region of Viet Nam and in areas close to Ho Chi Minh City as these locations are near urban centers with existing 
air quality problems. The RPDP VII changed the proposed sites for these thermal power stations, moving them away from population centers to lessen the impacts of air pollution.

The reduction in $\mathrm{CO}_{2}$ emissions was one of the reasons behind the revision of the original plan, and the analysis of the scenarios in RPDP VII showed significant differences in the total levels of $\mathrm{CO}_{2}$ emissions in the three RPDP VII scenarios (Table 8). In the revised plan, emissions are lower by almost 100 million tons per year by 2030 . This is a $25 \%$ decrease in the total predicted emissions in the original PDP VII, which is significant considering this represents almost three quarters of the total GHG emissions from the energy sector. As the energy sector accounts for one of the highest $\mathrm{CO}_{2}$ emissions in Viet Nam's economy, this difference represents a major contribution to the country's climate change mitigation efforts.

\section{Table 8: Total Carbon Dioxide Emissions in 2015-2030: Power Development Plan VII versus Revised Power Development Plan VII Scenarios} $\left(\mathrm{CO}_{2}\right.$ million tons)

\begin{tabular}{|lrrrr|} 
& 2015 & 2020 & 2025 & 2030 \\
\hline Original PDP VII (base case) & 107.16 & 201.49 & 297.24 & 443.8 \\
RPDP VII PA1 & 82 & 149.8 & 245.28 & 335.94 \\
RPDP VII PA2 & 82 & 149.82 & 244.83 & 335.38 \\
RPDP VII PA3 & 81.34 & 150.95 & 246.94 & 340.23 \\
\hline
\end{tabular}

$\mathrm{CO}_{2}=$ carbon dioxide, $\mathrm{PA}=$ Scenario No., RPDP VII = Revised Power Development Plan VII.

Source: Institute of Energy for Ministry of Industry and Trade. 2016. Report on Adjusted National Electricity Planning for 2011-2020, taking into consideration 2030. Ha Noi.

Viet Nam's Intended Nationally Determined Contributions (INDCs) on GHG mitigation, prepared for the 2015 Paris UNFCCC meeting, committed to an $8 \%$ reduction in emissions by 2030 , without international assistance, and $25 \%$ reduction with assistance compared to the business-as-usual scenario. ${ }^{14}$ The business-as-usual scenario pegs GHG emissions at 246.8 million tons of carbon dioxide $\left(\mathrm{tCO}_{2}\right)$ for the base year 2010, and projects an increase to 474.1 million $\mathrm{tCO}_{2}$ by 2020 and 787.4 million $\mathrm{tCO}_{2}$ by $2030 .{ }^{15}$ In this context, the savings of 100 million $\mathrm{tCO}_{2}$ of emissions per year by 2030, as stipulated in the RPDP VII, would be more than enough to meet the $8 \%$ target for mitigation in the country's INDCs. These figures alone would constitute a reduction of over $12 \%$ in the business-as-usual projected emissions for 2030. This means the changes made to the original PDP VII and contained in the RPDP VII, whichever scenario is considered, achieved the core policy objective of reducing the future impact of the power sector on $\mathrm{GHG}$ emissions.

An economic analysis of the costs of the different levels of GHG emissions was made based on a value of $\$ 8$ per ton of $\mathrm{CO}_{2}$ in the original PDP VII SEA. This figure was considered low by some commentators, but it reflected regional carbon market conditions at the time of

14 Government of Viet Nam. 2015. Intended Nationally Determined Contribution of Vietnam. Ha Noi.

15 N.T. Lam. 2015. Vietnam's GHG Emission Reduction Planning and Actions. Institute for Strategy and Policy on Natural Resources and Environment, Government of Viet Nam. 
the analysis in 2011 and was deemed appropriate by Vietnamese planners and authorities. Naturally, a higher figure would give proportionately higher impact values. Using $\$ 8$ under the original PDP VII proposals, the annual cost of GHG emissions was estimated to hit $\$ 1.6$ billion by 2020 and $\$ 3.55$ billion by 2030 , a huge amount relative to the overall cost of power generation.

The RPDP VII SEA adjusted the value to $\$ 10$ per ton to reflect inflation and the changing market conditions. In scenario PA1 of the revised plan, the economic cost of GHG emissions would be $\$ 1.5$ billion by 2020 and $\$ 3.35$ billion by 2030 -lower than the cost in the original PDP VII despite a higher per-ton cost. A recent report noted that "Viet Nam's emission growth is one of the highest in the world. These increases are mainly driven by the projected growth in the use of coal for power generation." That means any actions to reduce the GHG emissions from the power sector are of national and global significance and should be central to the country's approach to the mitigation of climate change impacts.

Analysis of the social and environmental externalities in the revised plan's scenarios inevitably focused on impacts from thermal power, especially coal. This is where the largest impacts would occur and where the government wanted significant reductions during the revision. The levels of reduction should meet government objectives without compromising the economic viability of investments in the sector. The combination of energy efficiency savings and alternative power sources meant that RPDP VII would more than meet national targets on energy efficiency and climate change mitigation.

As alternative power generation options were analyzed, it was found that the impacts stemming from investments in these alternatives were not very different from those in the original PDP VII. The largest of these alternative options, in terms of both power generated and potential impacts, was hydropower. Under all scenarios, investments in large-scale hydropower will reach its maximum viable potential by 2030 with a capacity of some 20,000 MW, which is not far from that proposed in the original PDP VII (Table 5). Because of this, the assessment and economic valuation of the hydropower proposals made in the original SEA for PDP VII were carried forward into the RPDP VII scenarios, with no changes to the proposed hydropower schemes in the revised plan. Social impacts such as resettlement costs, livelihood effects, and environmental/ecosystem service impacts on forests and water resources biodiversity were included in this analysis. The results of the calculation of the costs and benefits associated with these factors, that were traditionally treated as externalities, indicated that the economic viability of the hydropower investments was maintained even when these costs and benefits were included, along with the capital, and operations and maintenance costs. The same is true for the introduction of enhanced mitigation measures such as a resettlement program that meets international standards and the adoption of the Payment for Forest Ecosystem Services program, where hydropower schemes pay upland communities for watershed protection. The costs of all these measures did not affect the viability of hydropower investments.

The planned level of investment in nuclear power in RPDP VII was less than that in the original PDP VII, with the proposed capacity for 2030 reduced from 10,700 MW to

\footnotetext{
16 Ministry of Planning and Investment (MPI). 2015. Financing Vietnam's Response to Climate Change: Smart Investment for
} a Sustainable Future. MPI/World Bank/UNDP, Ha Noi. 
4,600 MW (Table 5). Concerns over the impacts of nuclear power remain the same as those analyzed in the original PDP VII SEA: the need to effectively manage radioactive materials and to carefully select sites for nuclear power. Nuclear power remains an option for Viet Nam but it would need huge investments in the development of both physical and institutional expertise to properly construct and operate nuclear power stations and their associated systems.

The RPDP VII includes a major expansion of renewable energy sources-other than large hydropower-from the proposals in the original plan (Table 5 and Table 6). Although it was not detailed, expansion under the revised plan would initially emphasize wind power and small-scale hydropower, which is planned and managed at the provincial level. Solar power is also expected to grow in future investments. Any risks of significant social and environmental impacts are considered to be small for renewable energy, provided that the sites selected for small-scale hydropower schemes are sensitive to local ecological and hydrological impacts (these are determined at the environmental impact assessment stage for such investments). The other major concern is the amount of land needed for investments in renewables. Solar power, particularly from large, consolidated solar farms, would require massive land areas. For renewable energy, the risks of negative impacts depend on the character of the sites selected and the measures taken during construction and operation to mitigate potential adverse effects. Many investments in renewable energy are anticipated to occur at a decentralized level, with private sector participation. As investments in renewables grow, the need for a stronger set of guidelines and regulations governing the development of renewable energy becomes more urgent.

The final area of impacts assessed in the SEAs of both the original and the revised power development plans involves the expansion of transmission lines to address growing demands and the need for a more integrated national transmission system. The loss of forest cover and fragmentation of sensitive ecosystems were a cause for particular concern in the original PDP VII SEA. Measures to reduce these impacts by rerouting proposed new transmission lines were recommended. The SEA of the RPDP VII showed that the potential impacts of expanding transmission lines was significantly reduced: the loss of high quality forests was slashed from 7,739 ha in the original plan to 2,663 ha in the revised plan proposals. The number of protected areas at risk from fragmentation also went down from 59 to 10 . This is noteworthy because there is no room for complacency; the remaining adverse impacts must be mitigated wherever possible.

\subsection{Conclusions}

The overall assessment shows that the impacts of the scenarios in the RPDP VII were not very different from each other: all showed a marked reduction of potential impacts, especially from thermal power, when compared with those in the SEA of the original power development plan. The RPDP VII proposed an expansion of Viet Nam's generating capacity to meet predicted future patterns of demand, but it also found ways to reduce potentially adverse impacts of such expansion without compromising the technical and financial viability of the proposals. The need to curb the rapid expansion of coal-fired power generation has led to a revised plan that reduced the negative impacts of power sector growth on the people and environment of the country. This clearly demonstrates the benefits of integrating an 
SEA in the strategic power sector planning system. It allows core government policies and development objectives to be incorporated in the plan proposals and provides a better understanding of the implications of different development approaches.

The use of SEAs in power development planning has evolved from the original SEA of PDP VI that focused on hydropower and was executed once the PDP was completed, to the SEA that was integrated into the revised PDP VII and helped define the overall plan. This change in the SEA's role in the power development planning process has benefited the country, but some challenges still need to be addressed before Viet Nam can be said to have a fully developed PDP process integrating an SEA. 


\section{Remaining Challenges for Developing Strategic Environmental Assessments of Power Development Plans}

\subsection{Introduction}

The narrative in this report describes the process of developing and integrating SEA in the PDP system in Viet Nam. Making the SEA a part of the PDP preparation has raised awareness and led to the inclusion of measures to mitigate the social and environmental impacts of scenarios in the PDP. It has also influenced the overall development of the power development planning process and helped outline the changes needed in the revision of PDP VII, moving away from the traditional focus on large generation options to a more diversified approach in which energy efficiency and renewable energy are more prominent. This, in turn, has closely aligned the PDP to national development priorities, reflecting policy innovations in recent years.

An important aspect of this evolution of the planning process is the development of capabilities of concerned institutions in Viet Nam and across the GMS. Since the pilot SEA started, ADB has provided training to those involved in the SEA process, specifically the Institute of Energy and other national institutions. This has strengthened institutional capabilities for SEA preparation and power sector planning in the country. It has also stimulated interest in the integration of SEA into PDP process across the subregion.

Another outcome of the experiences over the past decade is the consideration of how the planning process in the power sector should evolve to reflect the changing national policy framework, and international technological and energy market developments.

The integration of SEAs in the PDP process in Viet Nam still face several challenges, which include

(i) improving power system modelling programs;

(ii) improving the input database for power system modelling with a more detailed definition of cost of investments, and externalities and related benefits; and

(iii) improving the relationship between the planning processes at the national and provincial levels, especially concerning the development of renewable energy and the preparation of related SEAs at the provincial level.

Addressing these challenges will require conscious investments in capacity building and institutional strengthening. These investments have been instrumental in the development of the PDP system in the past, and they will continue to be essential in the future. 


\subsection{Improving Power System Modeling Programs}

The first challenge is the development of the modelling system used in the PDP to reflect the shift in focus from conventional large-scale generation options to a more diversified portfolio of activities in the plan, along with inclusion of environmental and social costs and benefits. PDP development, in anything other than a small-power system with a few sources of generation is highly dependent on generation, expansion models. Globally, there are many of these models, e.g., WASP IV, ASPLAN, PDPAT II, STRATEGIST, OptGen, and EPSIM. Each package has its own strengths and weaknesses. ${ }^{17}$ In Viet Nam, the Institute of Energy has used STRATEGIST and PDPAT II for the most recent PDPs. These are software that were provided under donor-supported projects some years ago.

The STRATEGIST program, licensed from ASEA Brown Boveri, a Swedish-Swiss multinational corporation, is used for expansion planning in Viet Nam. It is similar to WASP in that it can consider up to five hydrological conditions, provided such data have been taken from operating records and project feasibility studies.

The Institute of Energy's version of STRATEGIST is not the most recent available and has struggled with the modelling for RPDP VII. However, it has yet to be established whether this difficulty was due to limitations of the model or the way the software was applied. It is also unclear if there are more suitable software packages available.

In view of the above, access to suitable tools to enable proper inclusion within one model/program of costs and benefits defined by the SEA to the PDP remains a critical priority toward enhancing the power system planning process in Viet Nam.

\subsection{Improving Input Database for Power System Modeling}

A second area where further work is needed is the input database for the economic analysis of the PDP, in particular the valuation of nontraditional and nonfinancial costs. An important characteristic of an SEA, when applied in a strategic planning context, is that the full economic costs and benefits can be included in the analysis. This means the value of externalities, such as the cost of GHG emissions, air and water pollution, loss of amenity, and impact on endangered species, are quantified and included in the cost calculations for different power generation options. This is often referred to as "internalizing the externalities." When conducting an EIA on a single project, the costing of the main externalities may be appreciably simpler than when undertaking a wide-ranging PDP. Analysts need skills and contemporary databases to arrive at costings that are grounded in both international norms and local circumstances. This is an area where Viet Nam has required support in the past, and continues to be limited by both capacities and data availability.

17 For example, WASP has been around for decades and is freely available to national governments. However, it was originally developed for thermal systems, and the WASP IV version has only limited capability for hydro-thermal systems with extensive existing and candidate hydropower plants. All the interconnected systems in the GMS are hydro-thermal. 
While significant progress has been made in the abovementioned areas of economic analysis in the SEA of RPDP VII, improvements need to be made in certain calculations, including the generation of data that are still not widely available. This is necessary to build on efforts in the preparation of a PDP with a full economic analysis. The progress made to date is encouraging but not yet complete, and further work in this area is needed.

For example, while existing and candidate thermal plants are identified by name, installed capacity, and relative location within the RPDP VII reports, the investment, operating costs, and construction periods are only provided for different plant or fuel types, and not for individual plants. However, it should be noted that the application of the same unit investment cost and operating costs regardless of location means that significant differences in fuel transport and network connection costs have effectively been ignored within the expansion planning optimization process. The Institute of Energy has advised that this was due to a lack of the requisite data.

Similarly, existing and candidate large hydropower plants are identified by name, installed capacity, and relative location within the RPDP VII reports. However, according to the Institute of Energy, details of individual hydropower project investment costs and construction periods had not been available for input to the optimization process. Instead, the investment costs applied to large hydropower projects within the PDP VII derivation were based on the data for 13 hydropower plants constructed prior to 2015.

While in certain cases, the application of a sample unit investment cost (by proxy) may be judged to be acceptable, e.g., when applied to generic (i.e., non-location specific) plants, it is unusual for such an approach when dealing with hydropower plants of any significant size. This is because such projects will always be unique due to the influences of

(i) hydrology, in terms of inflow magnitude and variability;

(ii) layout, in terms of tunnels and spillways;

(iii) geology;

(iv) dam and reservoir size;

(v) available head and type of turbine;

(vi) physical location and access, as they affect construction costs, local transmission line costs, resettlement costs, and other environmental factors; and

(vii) construction conditions and periods, material availability, among others.

The abovementioned approach to defining the costs of large hydro and thermal power plants under RPDP VII ignores additional specific costs related to the individual location of these power plants, and therefore does not provide an adequate basis for optimizing their installation schedules in consideration of all related costs, energy output, and corresponding demand. In this regard, additional effort is needed to ensure the identification and application of location-specific individual costs of power plants in the future power system planning process in Viet Nam.

Collaboration with other Vietnamese institutions, including civil society and international nongovernment organizations, will build capacities in this area. There is much to learn from international standards of good practice in this field. The growing importance of energy 
efficiency and renewable energy, and the need to reflect national policies in fields such as climate change mitigation and green growth, emphasize the importance of strengthening this component of the PDP process.

\subsection{Improving Relationship between Power Sector Planning Processes in the National and Provincial Levels}

Another area that needs to be developed is the dynamics between the national and provincial levels of planning for the power sector. The increased role of renewable energy in power generation will also mean an increased role of provincial planning in the preparation and implementation of PDPs because smaller generation units (less than $30 \mathrm{MW}$ ) are prepared and executed at the provincial level. This highlights the need to equip provinces to plan for investments in renewable energy, as provinces must be able to integrate SEAs more effectively in their plan preparation. While this is a legal requirement, there are serious concerns over the capacity of provinces to implement SEAs. The Ministry of Natural Resources and Environment has identified the lack of capacity at the provincial level, both in Provincial People's Committees and among consultants, as the biggest constraint on the use of SEAs in strategic planning in Viet Nam. This will be a huge issue in the future as more investments in renewable energy (including smaller hydropower) enter the generation mix. The Ministry of Natural Resources and Environment believes it is crucial to have clear SEA guidelines for the power sector and a capacity-building program for provinces if the country is to build on the past success of SEA integration into the PDP process.

There is some experience of SEAs in relation to hydropower at the river basin or provincial level. ${ }^{18}$ One of the first SEAs undertaken in Viet Nam was the hydropower plan for the Vu GiaThu Bon River Basin. This study involved extensive stakeholder consultation and a detailed analysis of an existing plan that contains over 60 hydropower development proposals. These proposals had been submitted with no coordination or consideration of their cumulative impacts. The SEA demonstrated that the existing plan was unsustainable. It identified a set of criteria that must be used to assess whether a hydropower proposal would provide net benefits to the region. The SEA also presented mitigation and compensation measures that should be introduced where hydropower proposals were to be implemented. This study demonstrated that SEA at the subnational level is a feasible exercise that would benefit local sustainable development.

These remaining challenges suggest that, notwithstanding the progress made in recent PDP cycles, more work needs to be done to fully integrate SEAs into the PDP. This, in turn, suggests that the MOIT, as the responsible government agency, should prepare a methodological and procedural framework for a PDP that addresses these challenges, and thus, completely integrates SEA into power development planning; and reflects Vietnamese legislation and government procedures. Recent changes in legislation, such as the new Law on Planning and laws relating to decentralization, must be reflected in any changes to the power sector plan.

18 International Centre for Environmental Management. 2008. Strategic Environmental Assessment of the Quang Nam Province Hydropower Plan for the Vu Gia-Thu Bon River Basin. Ha Noi. 
Should these steps be taken to improve the PDP process, then the country can become an international model of good practice in modern power sector planning that takes account of all social and environmental impacts, and that is in a position to take advantage of the opportunities that the changing nature of energy technologies and markets will present in the coming years.

The next PDP VIII, which is being prepared for approval in 2020-2021, will be a great opportunity to reflect all the required changes and demonstrate suggested improvements. 


\section{Strategic Environmental Assessment Indicators and Evaluation Methods}

\begin{tabular}{|c|c|c|c|c|}
\hline $\begin{array}{l}\text { Generating } \\
\text { Source }\end{array}$ & Type of Impact & Indicators & Evaluation methods & Source of Information \\
\hline \multirow[t]{10}{*}{$\begin{array}{l}\text { Thermal } \\
\text { power }\end{array}$} & \multirow[t]{3}{*}{ Climate change } & \multirow{3}{*}{$\begin{array}{l}\text { 1. Total tons of GHG } \\
\text { emissions during power } \\
\text { generation } \\
2 \text { Economic cost of GHG } \\
\text { emissions }\end{array}$} & \multirow{3}{*}{$\begin{array}{l}\text { Calculate total } \mathrm{CO}_{2} \\
\text { emission by IPCC software } \\
\text { to be used for } \mathrm{GHG} \\
\text { inventory. } \\
\mathrm{CO}_{2} \text { price on the } \\
\text { international market at the } \\
\text { time of the preparation of } \\
\text { the SEA report. } \\
\text { Refer to www.investing. } \\
\text { com/commodities/carbon- } \\
\text { emissions. }\end{array}$} & \multirow{3}{*}{$\begin{array}{l}\text { The input data of thermal } \\
\text { power generation sources } \\
\text { are from RPDP VII of the } \\
\text { Institute of Energy. } \\
\mathrm{CO}_{2} \text { price on the } \\
\text { international market at the } \\
\text { time of the preparation of } \\
\text { the SEA report }\end{array}$} \\
\hline & & & & \\
\hline & & & & \\
\hline & \multirow[t]{2}{*}{ Acidification } & \multirow{2}{*}{$\begin{array}{l}\text { 1. Total } \mathrm{SO}_{2} \text { and } \mathrm{NO}_{x} \\
\text { emissions } \\
\text { 2. } \mathrm{pH} \text { value of water bodies } \\
\text { that could be affected } \\
\text { by flue gas from power } \\
\text { stacks }\end{array}$} & \multirow{2}{*}{$\begin{array}{l}\text { Calculate emissions } \\
\text { amount of } \mathrm{SO}_{2} \text { and } \mathrm{NO}_{x} \\
\text { and particulate with the } \\
\text { US EPA emission factors } \\
\text { applied. } \\
\text { Statistical data of water } \\
\text { quality to identify where } \\
\text { water quality can be } \\
\text { affected by acidification } \\
\text { because of emission from } \\
\text { power plants }\end{array}$} & \multirow{2}{*}{$\begin{array}{l}\text { The input data of thermal } \\
\text { power generation sources } \\
\text { are from RPDP VII of the } \\
\text { Institute of Energy. } \\
\text { Setting up a map of } \\
\text { pollutant emission } \\
\text { dispersion based on } \\
\text { emissions calculation } \\
\text { result from power plants } \\
\text { and collected data on air } \\
\text { and water quality }\end{array}$} \\
\hline & & & & \\
\hline & \multirow[t]{5}{*}{ Health impacts } & \multirow{5}{*}{$\begin{array}{l}\text { 1. Total PM emissions } \\
\text { 2. Number of people } \\
\text { exposed to health risks } \\
\text { from air pollutants }\end{array}$} & \multirow{5}{*}{$\begin{array}{l}\text { Identify the affected area } \\
\text { by GIS and estimate the } \\
\text { number of affected people. } \\
\text { Estimate of damage cost } \\
\text { for health care. }\end{array}$} & \multirow{3}{*}{$\begin{array}{l}\text { The statistical data of } \\
\text { population distribution in } \\
\text { the areas affected by flue } \\
\text { gas of power plants }\end{array}$} \\
\hline & & & & \\
\hline & & & & \\
\hline & & & & $\begin{array}{l}\text { The statistical data of } \\
\text { diseases in the areas } \\
\text { affected by flue gas from } \\
\text { power plants }\end{array}$ \\
\hline & & & & $\begin{array}{l}\text { Estimate of damage cost } \\
\text { for health care based on } \\
\text { the studied result of Mans } \\
\text { Nilson, SEl in } 2009 \text { of } \\
\text { the major environmental } \\
\text { program in Mekong } \\
\text { subregion. }\end{array}$ \\
\hline
\end{tabular}




\section{Appendix Table continued}

\begin{tabular}{|c|c|c|c|c|}
\hline $\begin{array}{l}\text { Generating } \\
\text { Source }\end{array}$ & Type of Impact & Indicators & Evaluation methods & Source of Information \\
\hline \multirow[t]{8}{*}{$\begin{array}{l}\text { Thermal } \\
\text { power }\end{array}$} & \multirow[t]{3}{*}{ Habitat loss } & \multirow{3}{*}{$\begin{array}{l}\text { 1. Total area of vulnerable } \\
\text { ecosystems } \\
\text { 2. Economic cost of } \\
\text { ecosystems loss }\end{array}$} & \multirow{3}{*}{$\begin{array}{l}\text { Identify the affected area } \\
\text { by GIS tool and estimate } \\
\text { the affected forest and } \\
\text { land areas. } \\
\text { Estimate the economic } \\
\text { value of forest ecosystem } \\
\text { services. }\end{array}$} & \multirow{3}{*}{$\begin{array}{l}\text { Data collection on forest } \\
\text { and key ecosystem } \\
\text { locations/areas } \\
\text { Estimate the economic } \\
\text { value of forest ecosystem } \\
\text { services and biomass } \\
\text { based on price rate } \\
\text { issued by the Ministry } \\
\text { of Agriculture and Rural } \\
\text { Development (MARD) }\end{array}$} \\
\hline & & & & \\
\hline & & & & \\
\hline & $\begin{array}{l}\text { Displaced } \\
\text { people }\end{array}$ & $\begin{array}{l}\text { Number of people } \\
\text { resettled }\end{array}$ & $\begin{array}{l}\text { Statistical data on } \\
\text { displacement of people by } \\
\text { power projects in 2010- } \\
2014 \text { in all provinces }\end{array}$ & $\begin{array}{l}\text { Institute of Energy issued } \\
\text { form to collect data from } \\
\text { all provinces }\end{array}$ \\
\hline & Cooling water & $\begin{array}{l}\text { Area of valuable } \\
\text { ecosystems exposed to } \\
\text { cooling waters }\end{array}$ & $\begin{array}{l}\text { Based on the information } \\
\text { of all feasibility study } \\
\text { dossiers of power plants } \\
\text { to identify impacted area } \\
\text { of valuable ecosystems by } \\
\text { cooling waters. }\end{array}$ & $\begin{array}{l}\text { Feasibility study dossiers of } \\
\text { thermal power plants }\end{array}$ \\
\hline & \multirow[t]{3}{*}{ Solid wastes } & $\begin{array}{l}\text { 1. Tons of waste products } \\
\text { from power generation }\end{array}$ & \multirow{2}{*}{$\begin{array}{l}\text { Calculate the solid waste } \\
\text { amount from coal-fired } \\
\text { power plants and other } \\
\text { plants for domestic and } \\
\text { hazardous waste. }\end{array}$} & \multirow[t]{3}{*}{$\begin{array}{l}\text { Calculation and statistical } \\
\text { data }\end{array}$} \\
\hline & & $\begin{array}{l}\text { 2. Land area for dumping } \\
\text { site }\end{array}$ & & \\
\hline & & & $\begin{array}{l}\text { Land occupied rate for } \\
\text { dumping site. }\end{array}$ & \\
\hline \multirow[t]{7}{*}{ Hydropower } & $\begin{array}{l}\text { Displaced } \\
\text { people }\end{array}$ & $\begin{array}{l}\text { Number of people } \\
\text { resettled }\end{array}$ & $\begin{array}{l}\text { Statistical data on } \\
\text { displacement of people by } \\
\text { power projects in the of } \\
2010-2014 \text { in all provinces }\end{array}$ & $\begin{array}{l}\text { Institute of Energy issued } \\
\text { form to collect data from } \\
\text { all provinces. }\end{array}$ \\
\hline & $\begin{array}{l}\text { Social and } \\
\text { livelihood } \\
\text { impacts }\end{array}$ & $\begin{array}{l}\text { Number of people affected } \\
\text { by hydropower projects }\end{array}$ & $\begin{array}{l}\text { Identify the impacted } \\
\text { area by GIS and estimate } \\
\text { the number of impacted } \\
\text { people. }\end{array}$ & $\begin{array}{l}\text { The statistical data of } \\
\text { population distribution } \\
\text { in the impacted areas by } \\
\text { hydropower plants }\end{array}$ \\
\hline & \multirow[t]{5}{*}{$\begin{array}{l}\text { Forest and } \\
\text { habitat loss }\end{array}$} & $\begin{array}{l}\text { 1. Total area of forest } \\
\text { cleared or suffering from } \\
\text { deterioration }\end{array}$ & \multirow{2}{*}{$\begin{array}{l}\text { Identify the impacted area } \\
\text { by GIS tool and estimate } \\
\text { the impacted forest and } \\
\text { land areas. }\end{array}$} & $\begin{array}{l}\text { Data collection on forest } \\
\text { and key ecosystem } \\
\text { locations/areas }\end{array}$ \\
\hline & & 2. The economic value & & \multirow{4}{*}{$\begin{array}{l}\text { Estimate the economic } \\
\text { value of forest ecosystem } \\
\text { services and biomass } \\
\text { based on price rate issued } \\
\text { by MARD. }\end{array}$} \\
\hline & & $\begin{array}{l}\text { of the losses of forest } \\
\text { resources }\end{array}$ & \multirow{3}{*}{$\begin{array}{l}\text { Estimate the economic } \\
\text { value of forest ecosystem } \\
\text { services. }\end{array}$} & \\
\hline & & $\begin{array}{l}\text { 3. Total area of vulnerable } \\
\text { ecosystems (ha) }\end{array}$ & & \\
\hline & & $\begin{array}{l}\text { 4. Economic cost of } \\
\text { ecosystem loss }\end{array}$ & & \\
\hline
\end{tabular}




\section{Appendix Table continued}

\begin{tabular}{|c|c|c|c|c|}
\hline $\begin{array}{l}\text { Generating } \\
\text { Source }\end{array}$ & Type of Impact & Indicators & Evaluation methods & Source of Information \\
\hline \multirow[t]{4}{*}{ Hydropower } & \multirow[t]{3}{*}{$\begin{array}{l}\text { Hydrological } \\
\text { impacts }\end{array}$} & $\begin{array}{l}\text { 1. Reduced downstream } \\
\text { water availability }\end{array}$ & \multirow{3}{*}{$\begin{array}{l}\text { Identify changes of water } \\
\text { level and flow of rivers and } \\
\text { springs in seasons as well } \\
\text { as before and after having } \\
\text { the hydropower plant; } \\
\text { transferring water from a } \\
\text { river to another one; length } \\
\text { of dried river section } \\
\text { downstream of a dam of a } \\
\text { hydropower plant. }\end{array}$} & \multirow{3}{*}{$\begin{array}{l}\text { Reference from a pilot } \\
\text { SEA for hydropower plant } \\
\text { plan in PDP VI, a study } \\
\text { on impacts of existing } \\
\text { hydropower plants in } \\
\text { the highland and central } \\
\text { region; and statistical data } \\
\text { from EIA of a feasibility } \\
\text { study of hydropower } \\
\text { plants. }\end{array}$} \\
\hline & & $\begin{array}{l}\text { 2. Length of aquatic } \\
\text { ecosystems affected } \\
(\mathrm{km})\end{array}$ & & \\
\hline & & $\begin{array}{l}\text { 3. Changes to dry season } \\
\text { water flows }\end{array}$ & & \\
\hline & $\begin{array}{l}\text { Biodiversity } \\
\text { loss/degradation }\end{array}$ & $\begin{array}{l}\text { Total area of vulnerable } \\
\text { ecosystems (ha) }\end{array}$ & $\begin{array}{l}\text { Identify the impacted area } \\
\text { by GIS tool and estimate } \\
\text { the impacted forest and } \\
\text { land areas. }\end{array}$ & $\begin{array}{l}\text { Data collection on forest } \\
\text { and key ecosystem } \\
\text { locations/areas }\end{array}$ \\
\hline \multirow[t]{5}{*}{$\begin{array}{l}\text { Nuclear } \\
\text { power }\end{array}$} & \multirow[t]{2}{*}{ Safety } & \multirow[t]{2}{*}{$\begin{array}{l}\text { Nuclear disasters and } \\
\text { safety principles for a } \\
\text { nuclear power plant. }\end{array}$} & $\begin{array}{l}\text { Evaluate technology and } \\
\text { safety principles for a } \\
\text { nuclear power plant and } \\
\text { radioactive issues. }\end{array}$ & $\begin{array}{l}\text { International standards } \\
\text { for management and } \\
\text { operation of a nuclear } \\
\text { power }\end{array}$ \\
\hline & & & $\begin{array}{l}\text { Identify causes of nuclear } \\
\text { disasters and their impact } \\
\text { scale. }\end{array}$ & $\begin{array}{l}\text { Solutions for nuclear } \\
\text { disasters from feasibility } \\
\text { study dossiers of nuclear } \\
\text { power plant projects, and } \\
\text { international references }\end{array}$ \\
\hline & \multirow[t]{2}{*}{$\begin{array}{l}\text { Radioactive } \\
\text { material } \\
\text { management }\end{array}$} & \multirow[t]{2}{*}{$\begin{array}{l}\text { Management system and } \\
\text { infrastructural condition in } \\
\text { the nuclear project areas. }\end{array}$} & \multirow{2}{*}{$\begin{array}{l}\text { Evaluate national and } \\
\text { international capacity } \\
\text { of radioactive material } \\
\text { management. }\end{array}$} & $\begin{array}{l}\text { International Atomic } \\
\text { Energy Agency standards } \\
\text { and guidelines. }\end{array}$ \\
\hline & & & & $\begin{array}{l}\text { Feasibility study dossiers } \\
\text { of nuclear power plant } \\
\text { projects. }\end{array}$ \\
\hline & Cooling water & $\begin{array}{l}\text { Area of valuable } \\
\text { ecosystems exposed to } \\
\text { cooling waters }\end{array}$ & $\begin{array}{l}\text { Based on the information } \\
\text { of feasibility study dossiers } \\
\text { of nuclear power plants to } \\
\text { identify areas of valuable } \\
\text { ecosystems affected by } \\
\text { cooling waters. }\end{array}$ & $\begin{array}{l}\text { Feasibility study dossiers of } \\
\text { nuclear power plants }\end{array}$ \\
\hline \multirow[t]{2}{*}{$\begin{array}{l}\text { Renewable } \\
\text { energy }\end{array}$} & $\begin{array}{l}\text { Land } \\
\text { occupation }\end{array}$ & $\begin{array}{l}\text { The land areas for } \\
\text { renewable energy projects. }\end{array}$ & $\begin{array}{l}\text { Note the land occupation } \\
\text { by renewable energy } \\
\text { projects }\end{array}$ & $\begin{array}{l}\text { Analysis and giving } \\
\text { warnings on matters of } \\
\text { renewable energy }\end{array}$ \\
\hline & Noise and vision & $\begin{array}{l}\text { Distance from project site } \\
\text { to residential area and } \\
\text { sensitive ecosystem or } \\
\text { valuable landscape }\end{array}$ & $\begin{array}{l}\text { Identify the impacts by } \\
\text { GIS tool and note the } \\
\text { distance from project } \\
\text { site to residential area } \\
\text { and sensitive ecosystem } \\
\text { or valuable landscape } \\
\text { that could be affected by } \\
\text { renewable energy projects. }\end{array}$ & $\begin{array}{l}\text { Analysis and giving } \\
\text { warnings on matters of } \\
\text { renewable energy }\end{array}$ \\
\hline
\end{tabular}




\section{Appendix Table continued}

\begin{tabular}{|c|c|c|c|c|}
\hline $\begin{array}{l}\text { Generating } \\
\text { Source }\end{array}$ & Type of Impact & Indicators & Evaluation methods & Source of Information \\
\hline \multirow[t]{11}{*}{$\begin{array}{l}\text { Transmission } \\
\text { lines }\end{array}$} & \multirow[t]{5}{*}{ Forest loss } & \multirow{5}{*}{$\begin{array}{l}\text { 1. Total area of forest } \\
\text { cleared or suffering } \\
\text { from deterioration in its } \\
\text { condition } \\
\text { 2. The economic value } \\
\text { of the losses of forest } \\
\text { resources } \\
\text { 3. Total area of vulnerable } \\
\text { ecosystems (ha) } \\
\text { 4. Economic cost of } \\
\text { ecosystems loss }\end{array}$} & \multirow{5}{*}{$\begin{array}{l}\text { Identify the affected area } \\
\text { by GIS tool and estimate } \\
\text { the affected forest and } \\
\text { land areas. } \\
\text { Estimate the economic } \\
\text { value of forest ecosystem } \\
\text { services. }\end{array}$} & $\begin{array}{l}\text { Data collection on forest } \\
\text { and key ecosystem } \\
\text { locations/areas }\end{array}$ \\
\hline & & & & \multirow{4}{*}{$\begin{array}{l}\text { Estimate the economic } \\
\text { value of forest ecosystem } \\
\text { services and biomass } \\
\text { based on price rate issued } \\
\text { by MARD }\end{array}$} \\
\hline & & & & \\
\hline & & & & \\
\hline & & & & \\
\hline & \multirow[t]{3}{*}{$\begin{array}{l}\text { Habitat } \\
\text { fragmentation }\end{array}$} & \multirow[t]{3}{*}{$\begin{array}{l}\text { Number and total area of } \\
\text { vulnerable ecosystems } \\
\text { fragmented }\end{array}$} & \multirow{3}{*}{$\begin{array}{l}\text { Estimate the affected } \\
\text { forest and land areas and } \\
\text { their fragmentation by GIS } \\
\text { tool. }\end{array}$} & $\begin{array}{l}\text { Data collection on forest } \\
\text { and key ecosystem } \\
\text { locations/areas }\end{array}$ \\
\hline & & & & $\begin{array}{l}\text { Information from RPDP VII } \\
\text { for transmission lines }\end{array}$ \\
\hline & & & & $\begin{array}{l}\text { Vietnamese regulation on } \\
\text { ROW }\end{array}$ \\
\hline & \multirow[t]{3}{*}{$\begin{array}{l}\text { Electromagnetic } \\
\text { field }\end{array}$} & \multirow[t]{3}{*}{$\begin{array}{l}\text { Number of people } \\
\text { affected by exposure to } \\
\text { electromagnetic field }\end{array}$} & \multirow{3}{*}{$\begin{array}{l}\text { Identify affected area } \\
\text { and estimate the number } \\
\text { of people exposed to } \\
\text { electromagnetic field by } \\
\text { GIS tool and Vietnamese } \\
\text { regulation on right of way. }\end{array}$} & $\begin{array}{l}\text { Data collection on forest } \\
\text { and key ecosystem } \\
\text { locations/areas }\end{array}$ \\
\hline & & & & $\begin{array}{l}\text { Information from RPDP VII } \\
\text { for transmission lines }\end{array}$ \\
\hline & & & & $\begin{array}{l}\text { Vietnamese regulation on } \\
\text { right of way }\end{array}$ \\
\hline
\end{tabular}

$\mathrm{CO}_{2}=$ carbon dioxide, $\mathrm{EIA}=$ Environmental Impact Assessment, EPA = Environmental Protection Agency, GHG = greenhouse gas, $\mathrm{GIS}=$ geographic information system, ha = hectare, $\mathrm{km}=$ kilometer, IPCC = Intergovernmental Panel on Climate Change, $\mathrm{NO}_{x}=$ nitrogen oxides, $\mathrm{PM}=$ particulate matter, ROW = right of way, RPDP VII = Revised Power Development Plan VII, $\mathrm{SEA}=$ Strategic Environmental Assessment, $\mathrm{SO}_{2}=$ sulfur dioxide.

Source: Institute of Energy, Viet Nam. 


\section{Integrating Strategic Environmental Assessment into Power Development Planning in Viet Nam}

This publication presents the integration of a Strategic Environmental Assessment (SEA) in the revised Power Development Plan VII of Viet Nam. It demonstrates how incorporating an SEA into the planning process will produce plans that are based on a more thorough understanding of their implications for the economy, society, and environment of the country. Viet Nam's revised Power Development Plan VII is a model of good practice in integrating an SEA in the preparation of a strategic plan for the power sector of other countries, particularly in the Greater Mekong Subregion.

\section{About the Asian Development Bank}

ADB is committed to achieving a prosperous, inclusive, resilient, and sustainable Asia and the Pacific, while sustaining its efforts to eradicate extreme poverty. Established in 1966, it is owned by 67 members48 from the region. Its main instruments for helping its developing member countries are policy dialogue, loans, equity investments, guarantees, grants, and technical assistance. 